\title{
Canonical transient receptor potential channels and their modulators: biology, pharmacology and therapeutic potentials
}

\author{
Yuan-Yuan Gao ${ }^{1}$ Wen Tian ${ }^{1} \cdot$ Hui-Nan Zhang ${ }^{1} \cdot$ \\ Yang Sun ${ }^{1} \cdot$ Jing-Ru Meng ${ }^{1} \cdot$ Wei $\mathrm{Cao}^{2}$. \\ Xiao-Qiang $\mathbf{L i}^{1}{ }^{1}$
}

Received: 25 July 2020 / Accepted: 14 March 2021 / Published online: 24 March 2021

(c) The Pharmaceutical Society of Korea 2021

\begin{abstract}
Canonical transient receptor potential channels (TRPCs) are nonselective, high calcium permeability cationic channels. The TRPCs family includes TRPC1, TRPC2, TRPC3, TRPC4, TRPC5, TRPC6, and TRPC7. These channels are widely expressed in the cardiovascular and nervous systems and exist in many other human tissues and cell types, playing several crucial roles in the human physiological and pathological processes. Hence, the emergence of TRPCs modulators can help investigate these channels' applications in health and disease. It is worth noting that the TRPCs subfamilies have structural and functional similarities, which presents a significant difficulty in screening and discovering of TRPCs modulators. In the past few years, only a limited number of selective modulators of TRPCs were detected; thus, additional research on more potent and more selective TRPCs modulators is needed. The present review focuses on the striking desired therapeutic effects of TRPCs modulators, which provides intel on the structural modification of TRPCs modulators and further pharmacological research. Importantly, TRPCs modulators can significantly facilitate future studies of TRPCs and TRPCs related diseases.
\end{abstract}

Xiao-Qiang Li

xxqqli@fmmu.edu.cn

1 Department of Pharmacology and Key Laboratory of Gastrointestinal Pharmacology of Chinese Materia Medica of the State Administration of Traditional Chinese Medicine, School of Pharmacy, Fourth Military Medical University, Xi' an, China

2 Department of Pharmacy, School of Chemistry \& Pharmacy, Northwest A\&F University, Yangling, China
Keywords Canonical transient receptor potential channels modulators · Calcium ion · High-resolution structures $\cdot$ Drug discovery $\cdot$ Therapeutic potentials

\section{Introduction}

The primary Transient Receptor Potential (TRP) protein was initially discovered in the experiment of aberrant visual transduction of Drosophila melanogaster (Cosens and Manning 1969). TRP channels (TRPs) feasibly form tetramers, a six-transmembrane domain structure with a cation-permeable pore loop between the fifth and sixth transmembrane domains (Hofmann et al. 2017). It is worth noting that there are differential expressions of TRPs in many tissues and cells and that TRPs show functional diversity and different pathological characters (Zhu et al. 2011). So far, the TRPs superfamily in mammalian is composed of 28 nonselective cation channels, and consists of several subfamilies: TRPC (canonical), TRPM (melastatin), TRPA (ankyrin), TRPV (vanilloid), TRPML (mucolipin), and TRPP (polycystin) (Zhu et al. 2011; Zheng 2013; Minard et al. 2018). The TRPC channels (TRPCs) family is the closest homolog to Drosophila TRP channels (Zheng 2013; Li 2017).

TRPCs are nonselective $\left(\mathrm{Ca}^{2+}, \mathrm{K}^{+}, \mathrm{Na}^{+}\right)$and high calcium permeability cationic channels. They are extensively expressed in many cells and tissues, including the lung, heart, brain, placenta, adrenal gland, retinal endothelial, testis, and kidney; they play crucial roles in many human physiological and pathological processes and are involved in various pathogenesis (Tai et al. 2017; Li et al. 2019b). TRPCs are activated by various chemical and physical stimuli through the phospholipase C (PLC) signaling pathway. For instance, TRPC1/4/5 homotetramers and heterotetramers channels are activated by Gq protein-coupled PLC and 
phosphatidylinositol 4,5-bi-sphosphate (PIP2) hydrolysis. This process generates inositol triphosphate (IP3) that binds to the endoplasmic reticulum IP3 receptor increasing extracellular $\mathrm{Ca}^{2+}$ entry called store-operated calcium entry (SOCE). Also, TRPC3/6/7 channels are unique in being directly activated by diacylglycerol (DAG), a degradation product of PIP2, which is known as receptor-operated calcium entry (ROCE) (Minke and Cook 2002; Jeon et al. 2012; Zheng 2013; Li et al. 2019b).

The present review focuses on the classification, structures, and function of TRPCs, as well as TRPCs modulators and their desired therapeutic effects, highlighting examples and opportunities for the application of TRPCs modulators in the pathology of various diseases.

\section{Classification of TRPCs}

TRPs were discovered in 1969 when the founding member of this superfamily was studying the $D$. melanogaster visual nerve transduction system (Cosens and Manning 1969). However, it was not until 1975 that the channels were named (Minke et al. 1975). Since the detection of TRPs, TRPC1 was the first human homolog of TRPs reported in 1995, but no further study for its functionality had been conducted yet (Wes et al. 1995). Over the following 3 years, five more novel related mammalian homologs (TRPC2-6) were detected, in addition to the functional expression of TRPC1 and TRPC 3 and the cloning and function of TRPC5 on the store- or receptor-operated $\mathrm{Ca}^{2+}$ entry (Zhu et al. 1996; Boulay et al. 1997; Okada et al. 1998). Additionally, another novel $\mathrm{Ca}^{2+}$ channel protein, TRPC7, was reported (Nagamine et al. 1998). At present, and considering the sequence homology, the seven mammalian TRPC subfamily members are subdivided into three subgroups: TRPC1/4/5, TRPC2, and TRPC3/6/7 (Zhu et al. 1995). Since human TRPC2 is most likely a pseudogene (Wissenbach et al. 1998), this review focuses on investigating TRPC1/4/5 and TRPC $3 / 6 / 7$ channels.

\section{Structure of TRPCs}

Ions channels modulate the flow of ions through the plasma membrane through temperature, chemical signals, electrical signals, or mechanical signals. Determining the channels' structure is crucial to understanding their molecular mechanisms (Moiseenkova-Bell and Wensel 2011). Along with the tremendous advancement of the electron cryo-microscopy (cryo-EM) technology, high-resolution structures have become an increasingly dominant method for determining the structure of many receptor complexes (Egelman 2016). This technological advancement has resulted in a revolution in the mammalian respiratory complex I structure (Agip et al. 2019). In the last few decades, the atomic models of macromolecular complexes were determined by X-ray crystallography (Egelman 2016). It was not until 2018 that the high-resolution structure of TRPCs was revealed ( $\mathrm{Li}$ et al. 2019a). Compared with classical X-ray crystallography, cryo-EM technology does not need to crystallize or diffract the protein/protein complex, and only uses a small number of samples. Owing to this advancing technology, membrane proteins' structure determination has become convenient, particularly for various ion channels (Li et al. 2019a; Wang et al. 2020a)

The current TRPCs structures reported had TRPC3, TRPC4, TRPC5, and TRPC6 channels (Fan et al. 2018; Duan et al. 2018, 2019; Azumaya et al. 2018; Vinayagam et al. 2018; Tang et al. 2018). The overall resolution of TRPCs in these reports is exceptionally similar, and they all showed that TRPCs are tetramer structures composed of homologous or heterologous monomers that contain six transmembrane spanning domains (Duan et al. 2018, 2019).

Many experiments showed that TRPC5 was closely related to TRPC4, with a $65 \%$ sequence identity (Duan et al. 2018). Mice TRPC4 and TRPC5 carry out protein purification ( $\mathrm{pH} 7.5$ ); then, they are used for the single-particle cryoEM analysis of the overall resolution of $3.3 \AA$ and $2.8 \AA$ in its unliganded (apo) state, respectively. TRPC4 poor densities are due to disordered regions; it consists of 4 residues in the S1-S2 loop, 2 residues in the S3-S4 loop, 27 residues in the distal $\mathrm{N}$ terminus, and 28 residues in the truncated distal $\mathrm{C}$ terminus, whereas TRPC5 is composed of 7 residues in the $\mathrm{S} 1-\mathrm{S} 2$ loop, 28 residues in the distal $\mathrm{N}$ terminus, and 3 residues in the truncated distal $\mathrm{C}$ terminus (Duan et al. 2018, 2019). The TRPC4 and TRPC5 structures are formed by a four-fold symmetric homotetramer with dimensions of $100 \AA$ by $100 \AA$ by $120 \AA$. Each of the four monomers consists of a unique compact cytosolic domain and a transmembrane domain (TMD), distinguishing it from other TRPs. The cytosolic domain is divided into two subdomains: the $\mathrm{N}$ terminus region with four ankyrin repeats domain of AR1 to AR4 and seven $\alpha$-helices domains of $\mathrm{H} 1$ to $\mathrm{H} 7$ and the $\mathrm{C}$ terminus region with a connecting helix and a coiled-coil domain. The TMD is composed of six helices ( $\mathrm{S} 1$ to S6), a TRP domain, and several small helices (Duan et al. 2018, 2019). In the TRPC4 and TRPC5 channels, the extracellular third transmembrane helix S3 region is made up of four helical turns, limiting potential extracellular interactions (Duan et al. 2019).

Compared with TRPC4 and TRPC5 channels, the extracellular S3 region in the TRPC3 and TRPC6 channels is a unique transmembrane domain that is remarkably long, constituting an extracellular region that can be used as a sensor of external stimuli (Fan et al. 2018; Duan et al. 2019). In the stable closed state, single-particle cryo-EM analyses 
revealed human TRPC6 (hTRPC6) channel with a newly identified high-affinity inhibitor [2-(benzo[d] [1,3] dioxol-5ylamino) thiazol-4-yl] [(3S, 5R)-3, 5-dimethylpiperidin-1-y1] methanone (BTDM), which has an overall resolution of $3.8 \AA$; it also revealed human TRPC3 (hTRPC3) channel with a lipid-activator OAG of $4.4 \AA$ resolution. The hTRPC 3 and hTRPC6 channels tetramer possesses dimensions of 75 by 75 by $150 \AA^{3}$. The TRPC 3 channel has four elbow-like membranes prior to the first transmembrane helix, while the TRPC6 channel has only three. The TRP helix is perpendicular to the pore-lining S6, and the hTRPC6 intracellular cytoplasmic domain presents an inverted bell shape whose top is below the ion channel pore of TMD (Fan et al. 2018; Tang et al. 2018). The truncation of the $\mathrm{N}$ terminus 71 amino acids is dispensable for the hTRPC6 assembly and gating, and the amino acids of TRPC6 cytoplasmic $\mathrm{C}$ terminus fold into two long helices (Tang et al. 2018). Novel electron cryoEM technology provides a structural basis for the function and gating mechanisms of TRPCs.

\section{TRPCs and diseases}

TRPCs are expressed in many cells and tissues and have been reported to be involved in the development and progression of various diseases, including cancers, kidney diseases, cardiovascular and nervous system diseases (Hwang et al. 2013; Sukumaran et al. 2017; Dryer et al. 2019; Falcon et al. 2020).

\section{Cardiovascular diseases}

$\mathrm{Ca}^{2+}$ plays a crucial role in maintaining physiological functions in the cardiovascular system, including diastolic cardiac function, cardiac contractility, and hemodynamic change (Tai et al. 2017; Wu et al. 2019). Several studies showed that TRPCs participate in cardiovascular system disease progression (Kitajima et al. 2016; Zhang et al. 2018b; Falcon et al. 2020). Wu et al. found that $\mathrm{Ca}^{2+}$ influx is increased in the hypertrophic myocytes of adult wild-type mice, while this phenomenon is not observed in the myocytes of dominant-negative (dn) TRPC $3 / 4 / 6$ adult mice (Wu et al. 2010). Additionally, the activity of the calcineurin-nuclear factor of activated T cells (NFAT) significantly decreases in dnTRPC3/4/6 mice (Wu et al. 2010). Over-expression of TRPCs could stimulate the activation of NFAT, which accelerates TRPCs expression through a positive feedback mechanism. The activation of this mechanism could contribute to the development of cardiac hypertrophy and hypertension (Watanabe et al. 2008; Wu et al. 2010). A previous study found that TRPC 3 can form a complex with A2R and PDE1C, and PDE1C is activated by TRPC3-invoked $\mathrm{Ca}^{2+}$, thereby facilitating cardiomyocyte apoptosis (Zhang et al. 2018b). Remarkably, a background $\mathrm{Ca}^{2+}$ entry pathway mediated by TRPC1/C4 can regulate $\mathrm{Ca}^{2+}$ cycling in cardiomyocytes. However, the pathological cardiac remodeling development is attenuated in transverse aortic constriction-induced TRPC1/4 double knockout mice (Camacho Londoño et al. 2015).

\section{Cancers}

TRPCs play a relevant role in the progression of different types of cancers, such as colorectal cancer, lung cancer, breast carcinoma, gastric cancer, renal cell carcinoma, hepatocellular carcinoma, and more (Wang et al. 2015b, 2018a; Jardin et al. 2018). Multiple studies provided evidence that the homeostasis of intracellular $\mathrm{Ca}^{2+}$ is disrupted in cancer cells and that the turbulence of $\mathrm{Ca}^{2+}$ signaling is concerned with tumor proliferation, migration, and invasion contributing to the overall tumor progression (Yang et al. 2009; Wang et al. 2015b; Jardin et al. 2018). One study reported that Trpc5-siRNA inhibits the Wnt/ $\beta$-catenin signal pathway, reduces $A B C A 1$ induction, and causes a prominent reversal resistance of 5-fluorouracil in human colorectal cancer cells (Wang et al. 2015b). However, the role of TRPCs is still controversial in breast cancer. On the one hand, hyperforin depresses the breast cancer's cell growth and viability in MDA-MB-231 cells, which may be due to over-activation of TRPC6, which disrupts $\mathrm{Ca}^{2+}$ signaling, thereby affecting cell proliferation (Aydar et al. 2009). On the other hand, TRPC6 knockdown by shTrpc6 significantly attenuates MCF7 and MDA-MB-231 cell proliferation (Jardin et al. 2018). Liang Wen et al. demonstrated that calcium dependence is an essential mechanism for regulating multi-drug resistance via the TRPC6/calcium/STAT3 signal pathway, and silencing TRPC6 elevates the efficacy of doxorubicin in hepatocellular carcinoma cells (Wen et al. 2016). Hong-Ni Jiang et al. found that overexpressing TRPC1 and TRPC6 increases the proliferation of the A549 lung cancer cell (Jiang et al. 2013). Notably, the TRPC6-NFAT pathway is activated by WNK1 promoting clear-cell renal-cell carcinoma cell proliferation and migration (Kim et al. 2019).

\section{Kidney diseases}

TRPC6 can accelerate the progression of many acquired glomerular diseases, such as glomerulosclerosis associated with autoimmune glomerulonephritis, primary and secondary focal and segmental glomerulosclerosis (FSGS), and type-1 diabetes (Dryer et al. 2019; Polat et al. 2019). Overactivation of the TRPC6 channel and Trpc6 gene mutations result in glomeruli injury (Dryer et al. 2019; Staruschenko 
et al. 2019). It is worth noting that reactive oxygen species and angiotensin II (AngII) are the two major factors that provoke dramatic increases of TRPC6-mediated $\mathrm{Ca}^{2+}$ influx in diabetic kidney disease, resulting in hypertrophy and the death of podocytes (Ilatovskaya et al. 2015; Ma et al. 2016; Staruschenko et al. 2019). TRPC6 antagonist, BTP2, attenuates renal fibrosis and glomerulosclerosis in TRPC6-knockout mice (Wu et al. 2017a). However, Wang et al. revealed that TRPC6 knockout reduces proteinuria and decreases tubule injury but increases mesangial expansion and promotes insulin resistance, causing exacerbation of diabetic kidney disease in Akita mice (Wang et al. 2019c). AngII and endothelin-1-induced mesangial contraction are significantly decreased with the downregulation of TRPC1 in TRPC1 antibody-treated rats. Hence, TRPC1 could play a specific role in regulating mesangial cell contractility (Woudenberg-Vrenken et al. 2009). Studies have indicated that TRPC5 blocker, AC1903, could successfully protect podocytes injury in vitro and the kidney filter function in vivo; thus, TRPC 5 could be a potential therapeutic target for FSGS (Pablo and Greka 2019).

\section{Nervous system diseases}

TRPCs participate in the formation of synapses and the modulation of neurotransmitter release; this involvement of TRPCs plays a vital role in the neurological system's functions, such as memory, movement, cognition, anxiety, and fear (Riccio et al. 2014; Hong et al. 2015). TRPCs are primarily expressed in the brain, which is susceptible to oxidative stress. The TRPC5-like current activated by oxidized glutathione increases $\mathrm{Ca}^{2+}$, which ultimately induces striatal neuronal cell death. TRPC5 inhibition by ML204 predominantly attenuates oxidation-provoked striatal neuronal cell death and improves motor and rearing behavior in Huntington's disease transgenic mice (Hong et al. 2015). Many factors contribute to Parkinson's disease, such as excitotoxicity, mitochondrial dysfunction, endoplasmic reticulum stress, reactive oxide species, and inflammation; almost all of them depend directly or indirectly on $\mathrm{Ca}^{2+}$ signaling (Sukumaran et al. 2017). Reduction in apoptosis and $\mathrm{Ca}^{2+}$ influx provides neuroprotection via activation of TRPC1 (Thapak et al. 2020). Studies have shown that TRPC6 specifically inhibits its cleavage by $\gamma$-secretase of amyloid precursor protein (APP) and reduces $\beta$-amyloid formation by preventing APP from interacting with presenilin 1, which could be a novel strategy for treating Alzheimer's disease (Wang et al. 2015a). At the same time, neurotoxic TRPC6-mediated $\mathrm{Ca}^{2+}$ entry is mediated by presenilin 2 . Activation of TRPC6 increases adult hippocampal neurogenesis and long-term spatial memory but reduces $\mathrm{A} \beta$ accumulation due to increased cerebrovascular P-glycoprotein
(Thapak et al. 2020). Antonio Riccio et al. reported that $\mathrm{TRPC}^{-1-}$ mice displays decreased anxiety-like behavior and Gq/11-dependent responses (Riccio et al. 2014). Similarly, TRPC $1 / 4 / 5$ blocker, HC-070, alleviates anxiety and depression in mice (Just et al. 2018). Inhibition of TRPC6 degradation by calpain inhibitors prevents ischemic neuronal death, improves behavioral performance, and provides neuroprotection through the Ras/MEK/ERK/CREB pathway (Thapak et al. 2020).

\section{Other diseases}

Some reports have shown that TRPCs are involved in other diseases, such as obesity, type II diabetes, and lung diseases (Yu et al. 2004; Krout et al. 2017). TRPC3/6 expression in the lung tissues and pulmonary artery smooth muscle cells of idiopathic pulmonary arterial hypertension patients was much higher than those normotensive or secondary pulmonary hypertension patients (Yu et al. 2004). It has been reported that hypoxia-inducible factor-1 boosts the expressions of TRPC1 and TRPC6 increasing intracellular $\mathrm{Ca}^{2+}$ level in pulmonary artery smooth muscle cells (Wang et al. 2006). Another study suggested that TRPC1 plays a crucial role in adiposity via inducing autophagy and apoptosis; moreover, high-fat diet-induced obesity and type II diabetes were alleviated in TRPC1 knockout mice (Krout et al. 2017).

\section{TRPCs agonists}

\section{TRPC5 channel}

\section{Methylprednisolone}

The glucocorticoid methylprednisolone is a long-acting, reversible TRPC5 agonist with $\mathrm{EC}_{50}$ of $12 \mu \mathrm{M}$, which is effectively inhibited by clemizole. Methylprednisolone only activates the TRPC5 channel and does not affect other TRPC subfamily members; however, the carbachol-induced TRPC4 channel can also be activated by methylprednisolone. Prednisolone can also act as a weak activator of TRPC5 channels with $\mathrm{EC}_{50}$ of $64 \mu \mathrm{M}$ (Beckmann et al. 2017). One study has demonstrated that local delivery of methylprednisolone succinate in combination with a copolymer of ethylene oxide and propylene oxide facilitates spinal cord sensorimotor circuitry and increases excitability (Baltin et al. 2021). Additionally, methylprednisolone acetate administration intraarticularly or intravenously has shown to improve the lung function of horses and infants with severe asthma and bronchopulmonary dysplasia, respectively (Millares-Ramirez et al. 2021; Billion et al. 2021; Wang et al. 2021a). 
AM237

AM237, a xanthine derivative synthesized compound, potently activates the TRPC5:C5 channel with $\mathrm{EC}_{50}$ of 15-20 nM in $\mathrm{Ca}^{2+}$ assays. AM237 does not activate either the TRPC4-C1, TRPC5-C1, TRPC4:C4, TRPC1:C5, TRPC1:C4 channels, or native TRPC1:C4 channel in A498 cells; instead, it suppresses the activation evoked by (-)-englerin A (Minard et al. 2019).

\section{GW-1929}

A rosiglitazone-related peroxisome proliferator-activated receptor- $\gamma$ (PPAR- $\gamma$ ) agonist, $N$-(2-benzoylphenyl)- $O$ - [2(methyl-2-pyridinylamino)ethyl]-L-tyro-sine (GW-1929), can weakly stimulate the TRPC5 channel (Majeed et al. 2011). GW1929 inhibits TRPC1 and TRPC6 expressions in the pulmonary artery smooth muscle cells through the activation of PPAR $\gamma$ (Lu et al. 2010; Wang et al. 2013).

\section{TRPC6 channel}

\section{Hyperforin}

Hyperforin is isolated from the leaves, stems, and roots of the dried herb Hypericum perforatum L (St John's wort); it has been used for mild to moderate depression, multidrugresistant Staphylococcus aureus, and (other) gram-positive bacteria (Laakmann et al. 1998; Orth et al. 1999; Ebrey 1999; Singer et al. 1999; Szewczyk et al. 2019). Hyperforin is a specific and highly selective activator of the TRPC6 channel without activating TRPC1/4/5 and TRPC $3 / 7$ channels (Leuner et al. 2010; Tu et al. 2010). Hyperforin has a neuroprotective effect by reducing aluminum-induced $\mathrm{A} \beta$ production and tau phosphorylation against Alzheimer's disease $(\mathrm{AD})$, which could provide a potential $\mathrm{AD}$ therapy (Huang et al. 2017; Jiang et al. 2018; Wang et al. 2019a). TRPC6 channel activation can attenuate brain damage (Lin et al. 2013) and substantially improve recurrent moderate hypoglycemia-induced cognitive impairment (He et al. 2020). Hyperforin has also been demonstrated to promote post-stroke neurovascular regeneration and functional recovery via astrocytic IL-6-mediated negative immune regulation (Yao et al. 2019) and improve post-stroke social isolation-induced exaggeration of post-stroke depression and post-stroke anxiety via TGF- $\beta$ (Zhang et al. 2019). Additionally, hypericum extracts have been reported to have a protective effect on the brain, improve anxiety-like behavior (Sevastre-Berghian et al. 2018) and exhibit an antidepressant-like activity in mice (Pochwat et al. 2018). Besides, as a specific activator for TRPC6, hyperforin usage could reduce the growth and viability of the various human and rat cancer cell lines by apoptosis with $\mathrm{IC}_{50}$ between 3 and $15 \mu \mathrm{M}$ (Schempp et al. 2002; Chen et al. 2018; Liu et al. 2019). The anti-tumor activity of $H$. perforatum $\mathrm{L}$. and hyperforin has been proven to be linked with mediating inflammatory signaling, ROS generation, and proton dynamics, as well as exhibiting antiproliferative effects (Allegra and Tonacci 2020). Hyperforin causes apoptosis through extrinsic/intrinsic pathways and inhibits NF-kB-mediated invasion, enhancing the survival potential in bladder cancer and non-small cell lung cancer (Chen et al. 2018; Liu et al. 2019); it also inhibits the EGFR/ $\mathrm{ERK} / \mathrm{NF}-\kappa \mathrm{B}-$ modulated anti-apoptotic potential in glioblastoma (Hsu et al. 2020). Hyperforin could prevent parental and oxaliplatin-resistant human adenocarcinoma cells' metastasis through anti-adhesion therapy (Šemeláková et al. 2018). TRPC6 activation stimulates the differentiation and proliferation of keratinocytes, playing a significant role in treating atopic dermatitis and psoriasis; therefore, hyperforin presents an innovative therapeutic strategy in skin disorders (Takada et al. 2017). Additionally, TRPC6 gene silencing through ryanodine receptor type 1 can partially ameliorate muscle cation dyshomeostasis and the halothane's response to malignant hyperthermia in a mouse model (Lopez et al. 2020b). Hyperforin also prevents the growth of infectioninduced inflammatory responses of glial cells and neurotropic parasite Toxoplasma gondii (Shinjyo et al. 2021).

\section{$O A G$}

Leuner et al. (2010) demonstrated that 2, 4-diaetylphloroglucinol derivative has the pharmacophore of diacylglycerol and hyperforin; it is also TRPC6 selective. Tesfai et al. (2001) revealed that the membrane-permeant analogs of DAG initiate the activation of $\mathrm{Ca}^{2+}$ inflow in the adrenal chromaffin cell line (PC12 cell); similarly is the permeant DAG analog 1-oleoyl-2-acetyl-sn-glycerol (OAG) effect (Hofmann et al. 1999; Tesfai et al. 2001; Venkatachalam et al. 2003; Tu et al. 2009; Fuchs et al. 2011). It has been reported that the TRPC6 channel is essential for acute hypoxic pulmonary vasoconstriction (HPV) in mice. Under the condition of repetitive hypoxic ventilation, OAG dosedependently attenuates the strength of acute HPV by TRPC6 channel activation (Fuchs et al. 2011).

\section{0-HETE}

20-hydroxyeicosatetraenoic acid (20-HETE) is an eicosanoid compound that can activate the TRPC6 channel in the HEK293 cell line, Hek-t6.11 with $\mathrm{EC}_{50}$ of $0.8 \mu \mathrm{M}$ (Basora et al. 2003).

\section{Flufenamic acid}

Flufenamic acid is a non-steroidal anti-inflammatory that belongs to the fenamates family and can induce the TRPC6 
Table 1 TRPCs agonists (1)

\begin{tabular}{|c|c|c|c|c|}
\hline Modulators & Chemical structure & Targeting channels and IC50 & Predicted effects & Reference \\
\hline Methylprednisolone & & $12 \mu \mathrm{M}$ (TRPC5:C5) & $\begin{array}{l}\text { Activate TRPC5 channel and } \\
\text { improve the lung function }\end{array}$ & $\begin{array}{l}\text { Beckmann et al. (2017), Millares- } \\
\text { Ramirez et al. (2021) }\end{array}$ \\
\hline AM237 & & 15-20 nM (TRPC5:C5) & $\begin{array}{l}\text { Suppress activation evoked by } \\
(-) \text {-EA }\end{array}$ & Minard et al. (2019) \\
\hline GW-1929 & & TRPC5:C5 & $\begin{array}{l}\text { a Rosiglitazone-related PPAR- } \gamma \\
\text { agonist }\end{array}$ & $\begin{array}{l}\text { Lu et al. (2010), Majeed et al. } \\
\text { (2011) }\end{array}$ \\
\hline Hyperforin & & 3-15 $\mu \mathrm{M}$ (TRPC6) & $\begin{array}{l}\text { Mild to moderate depression, } \\
\text { inhibit bacteria, Alzheimer's } \\
\text { disease, the various human and } \\
\text { rat cancer cell lines }\end{array}$ & Jiang et al. (2018), Liu et al. (2019) \\
\hline OAG & & TRPC3/6/7 & $\begin{array}{l}\text { The activation of } \mathrm{Ca}^{2+} \text { inflow, } \\
\text { acute HPV in mice }\end{array}$ & Fuchs et al. (2011) \\
\hline 20-HETE & & $0.8 \mu \mathrm{M}$ (TRPC6) & $\begin{array}{l}\text { Activate TRPC6 channel in } \\
\text { HEK293 cell line, Hek-t6.11 }\end{array}$ & Basora et al. (2003) \\
\hline Flufenamic acid & & TRPC6 & Non-steroidal anti-inflammatory & Foster et al. (2009) \\
\hline
\end{tabular}

expression; it also does not significantly affect TRPC7 expression and reduces TRPC3 expression (Foster et al. 2009). Blocking the TRPC 3 channel by flufenamic acid modulates the depolarization of cholinergic interneurons (Xie and Zhou 2014). Increased expression of TRPC6 by flufenamic acid promotes cell proliferation in human megakaryocytes (Ramanathan and Mannhalter 2016) (Table 1).

\section{TRPC1/5 channels}

\section{Riluzole}

Riluzole is a marketed drug that plays a role in the survivability of amyotrophic lateral sclerosis (ALS) and acts as an antidepressant (Miller et al. 2000; Grant et al. 2010; Minard et al. 2018). Richter et al. (2014b) identified riluzole as a novel TRPC 5 channel agonist with $\mathrm{EC}_{50}$ of $9.2 \mu \mathrm{M}$. Riluzole can activate the heteromeric TRPC1:C5 channel expressed in HEK293 cells and the endogenous TRPC5:C5 channel expressed in the U-87 glioblastoma cell lines. The riluzole-induced TRPC5 activation mechanism is independent of G protein signaling and PLC activity as it differs from the $\mathrm{La}^{3+}$-mediated TRPC5 activation. Finally, the recordings of excised inside-out patches demonstrated that riluzole has a relatively direct effect on TRPC5 activation. Riluzole improves recovery from ischemia in mice through TRPC5 activation in the endothelial cells (Zhu et al. 2019). Additionally, riluzole has neuroprotection and therapeutic application to prevent oxaliplatin-induced neuropathy (Trinh et al. 2021). Riluzole can also treat severe hyponatremia secondary to amyotropic lateral sclerosis (Tambe et al. 2021).

\section{Rosiglitazone}

Rosiglitazone, a high-affinity PPAR- $\gamma$ ligand, can activate TRPC5 with $\mathrm{EC}_{50}$ of about $30 \mu \mathrm{M}$. The effects of rosiglitazone on TRPC5 occur rapidly and reversibly on washout (Majeed et al. 2011). It has been reported that rosiglitazone also activates the heteromeric TRPC1:C5 channel. Rosiglitazone (as a thiazolidinedione) is an antidiabetic drug that acts as an insulin sensitizer. Rosiglitazone decreases free fatty acids released from adipocytes to ameliorate skeletal muscle insulin resistance. Rosiglitazone can also inhibit angiotensin II-induced proliferation of rats' glomerular mesangial cells via the Goq/Plc $\beta 4 /$ TRPC signaling pathway (Wei et al. 2017b). Moreover, rosiglitazone ameliorates rat radiation-induced intestinal inflammation by inhibiting NLRP3 inflammasome and TNF-alpha production (Hu et al. 2020a). The development and progression of endometriosis are impacted by rosiglitazone likely by inhibiting angiogenesis and inducing apoptosis (Zhang et al. 2021). Rosiglitazone treatment improves cognitive areas that mainly depend on the dorsal hippocampus (Cortez et al. 2020). However, it has been withdrawn from clinical use in most countries due to its side effects, such as heart attacks and sudden death (Rubaiy 2019; Gong et al. 2020). 


\section{TRPC3/6 channels}

\section{Artemisinin}

Artemisinin has been identified as a well-known TRPC3 channel agonist; it was discovered by screening 2000 bioactive compounds in a $\mathrm{Ca}^{2+}$ influx assay (Urban and Schaefer 2020). Artemisinin has a strong stimulatory effect on TRPC3 or heteromeric TRPC3:C6 channels, and it weakly affects the TRPC6 and TRPC7 channels, or these channels lack the response to artemisinin (Urban and Schaefer 2020). Artemisinin is an antimalarial agent isolated from the Chinese medicinal plant Artemisia annua L. (Liu et al. 2011; Stringham et al. 2018) and has been used as an effective treatment for malaria (Wang et al. 2021b; van der Pluijm et al. 2021). At the same time, artemisinin, as a novel anti-cancer drug, targets a global cancer pandemic through drug repurposing (Xu et al. 2020; Augustin et al. 2020). Furthermore, Bai et al. (2020) revealed the vital role of $\mathrm{pH}$-dependent molecular rearrangement in the activation and activity of artemisinin against cancer. Interestingly, artemisinin and its derivatives may be valuable in treating obesity and diabetes (Shen et al. 2020; Jiang et al. 2020b). Artemisinin can also ameliorate inflammation by suppressing the process of epithelial-mesenchymal transition and inducing macrophage polarization to the M2 phenotype, which may help treat inflammatory bowel disease in the future (Huai et al. 2020). Zhou et al. (2020) discovered novel artemisinin derivatives through structural optimization of artemisinin that works against liver and ovarian cancers.

\section{GSK1702934A}

GSK1702934A is a small 1,3-dihydro-2H-benzo[d]midazole-2-one-based potent agonist that activates TRPC3/6 channels directly with $\mathrm{EC}_{50}$ of $0.08 \mathrm{mM}$ and $0.44 \mathrm{mM}$, respectively. Whole-cell patch-clamp experiments have proven that GSK1702934A can activate the TRPC3/6-currents in HEK293 cells (de la Cruz et al. 2017). Cardiovascular morbidity and mortality are associated with increased blood pressure variability (BPV). Activation of TRPC6 by GSK1702934A exacerbates the systolic and diastolic BPV (Wang et al. 2020d), while TRPC3 activation substantially contributes to cardiac contractility control and arrhythmogenesis (Doleschal et al. 2015).

\section{TRPC1/4/5 channels}

\section{Tonantzitlolone}

Tonantzitlolone is extracted from the Mexican plant Stillingia sanguinolenta; it has been used against fibroblasts cells in mice and certain types of human cancer cells, such as human breast cancer cells and renal cell carcinoma cells (Jasper et al. 2005; Busch et al. 2016; Pfeffer et al. 2016; Rubaiy et al. 2018). In the NCI-60 human tumor cell lines screen, many of the sixty cancer cells were resistant to tonantzitlolone in nanomolar concentrations, indicating that tonantzitlolone could have a beneficial effect on specific subtypes of cancer cells (Rubaiy et al. 2018). Tonantzitlolone works against renal cancer cells through protein kinase $\mathrm{C}$ isoform $\theta$ - and heat shock factor 1-dependent (Sourbier et al. 2015). Though the profile of tonantzitlolone in this screen is exceptionally parallel to (-)-englerin A, the structures of tonantzitlolone and (-)-englerin A are entirely distinguishable from each other (Rubaiy et al. 2018; Rubaiy 2019).

Rubaiy et al. (2018) revealed that tonantzitlolone is a novel potent agonist for TRPC4, TRPC5, TRPC4-TRPC1, and TRPC5-TRPC1 channels with $\mathrm{EC}_{50}$ of $123 \mathrm{nM}, 83 \mathrm{nM}$, $140 \mathrm{nM}$, and $61 \mathrm{nM}$, respectively, which could be useful for investigating the function of these ion channels. However, tonantzitlolone could not activate endogenous SOCE in HEK 293 cells and over-expressed the TRPC3, TRPV4, and TRPM2 channels. In whole-cell patch-clamp recordings, tonantzitlolone was washed-out reversibly and inhibited potently by Pico145, a TRPC1/4/5 inhibitor (Rubaiy et al. 2017b). Tonantzitlolone A and its synthetic enantiomer inhibit cell proliferation and kinesin-5 function, and the synthetic enantiomer shows a more potent inhibitory effect; thus, it is possible to enhance the anti-proliferative effect of tonantzitlolon A by chemical modification (Pfeffer et al. 2016).

\section{(-)-englerin A}

Similar to tonantzitlolone, (-)-englerin A is a guaian-type sesquiterpene and a natural product that originates from the Tanzanian plant Phyllanthus engleri; it is isolated and fractionated from the roots and bark of this plant (Ratnayake et al. 2009). Ratnayake et al. (2009) revealed that (-)-englerin A has 1000-fold selectivity to six of the eight renal cancer cell lines with $\mathrm{GI}_{50}$ between 1 and $87 \mathrm{nM}$. (-)-englerin A can selectively inhibit the growth of renal cancer cell lines in the NCI-60 cytotoxicity screen. However, its use in the pharmaceutical treatment of cancer is limited due to its instability and toxicity (Akbulut et al. 2015; Wu et al. 2017b; Grant et al. 2019; Rubaiy 2019). Although (-)-englerin A has selective cytotoxic to cancer cells, adverse reactions in mice and rats have been reported. One study found that TRPC4 and TRPC5 single knockout mice were partially protected from adverse reactions, and double knockout mice were fully protected (Cheung et al. 2018). 
Moreover, (-)-englerin A directly activates PKC $\theta$ to limit the access of tumor cells to glucose, resulting in glucose dependence and insulin resistance in tumor cells through the activation of heat shock transcription factor, HSF1, and insulin receptor substrate 1 (IRS1) (Muraki et al. 2017).

(-)-englerin A is a highly selective and potent activator of both homomeric and heteromeric TRPC1/4/5 channels, which helps study these proteins' pharmacological action (Akbulut et al. 2015; Minard et al. 2018; Rubaiy 2019). (-)-englerin A could activate TRPC1/4/5 channels to influence A498 renal cancer cells (Haque et al. 2017). Acute inflammatory response induced by (-)-englerin A could modulate anti-tumor immunity. Additionally, Batova et al. (2017) revealed that lipid metabolism and ER stress could be targeted vulnerabilities in renal cell carcinoma. However, (-)-englerin B, a (-)-englerin A metabolic product, could not activate TRPC1/4/5 channels to influence A498 renal cancer cells (Wu et al. 2017b). As stated, (-)-englerin A is a potent TRPC4:C4 and TRPC5:C5 channels activator in HEK293 cells with $\mathrm{EC}_{50}$ of $11.2 \mathrm{nM}$ and $7.6 \mathrm{nM}$, respectively (Akbulut et al. 2015). (-)-englerin A may have a similar activating effect on TRPC1:C4 and TRPC4-containing channels, but it does not affect TRPC6, TRPM2, TRPV4 channels, 10 other ion channels, and 59 GPCRs (Akbulut et al. 2015; Minard et al. 2018). Grant et al. (2019) showed that (-)-englerin A-evoked cytotoxicity results in rapid cancer cell death in two different triple-negative breast cancers cancer cells, BT-549 and Hs578T.
$B T D$

Beckmann et al. identified a novel TRPC5 agonist, which is $\mathrm{N}$-[3-(adamantan-2-yloxy)propyl]-3-(6-methyl-1, 1-dioxo-2H-1 $1 \lambda^{6}, 2,4$-benzothiadiazin-3-yl)propanamide (BTD) with $\mathrm{EC}_{50}$ of $1.4 \mu \mathrm{M}$ in $\mathrm{Ca}^{2+}$ assays and $\mathrm{EC}_{50}$ of $1.3 \mu \mathrm{M}$ in the electrophysiological whole-cell patch-clamp recordings from screening the ChemBioNet compound library (Beckmann et al. 2017). BTD is long-lasting, reversible, and sensitive to clemizole, which is a TRPC5 blocker. Furthermore, BTD displayed selectivity to TRPC1/4/5 channels; it can activate the homomeric TRPC5:C5 channel as well as the heteromeric TRPC1:C5 and TRPC4:C5 channels, and to a less extent, the TRPA1, TRPV1, TRPM3, and TRPM8 channels; however, it does not activate the TRPC4:C4 and TRPC1:C4 channels (Beckmann et al. 2017) (Table 2).

\section{TRPC3/6/7 channels}

$4 m-4 p$

$4 m-4 p$ are a series of potent and direct agonists of TRPC 3/6/7 channels belonging to pyrazolopyrimidines (Qu et al. 2017). They activate the TRPC $3 / 6 / 7$ channels with a potency order of TRPC $3>\mathrm{C} 7>\mathrm{C} 6$. One of the $4 \mathrm{n}$ is the most potent with $\mathrm{EC}_{50}$ of $<20 \mathrm{nM}$ for TRPC 3 channel activation.

Table 2 TRPCs agonists (2)

\begin{tabular}{|c|c|c|c|c|}
\hline Modulators & Chemical structure & Targeting channels and IC50 & Predicted effects & Reference \\
\hline Riluzole & & $\begin{array}{l}9.2 \mu \mathrm{M}(\mathrm{TRPC} 5: \mathrm{C} 5) \\
\text { TRPC1:C5 }\end{array}$ & ALS and anti-depressant & Richter et al. (2014b) \\
\hline Rosiglitazone & & $\begin{array}{l}\sim 30 \mu \mathrm{M}(\mathrm{TRPC} 5: \mathrm{C} 5) \\
\text { TRPC1:C5 }\end{array}$ & $\begin{array}{l}\text { An antidiabetic drug and an } \\
\text { insulin sensitizer }\end{array}$ & Majeed et al. (2011) \\
\hline artemisinin & & TRPC3, TRPC3:C6 & $\begin{array}{l}\text { Antimalarial agent; anti-cancer } \\
\text { drug }\end{array}$ & $\begin{array}{l}\text { Urban and Schaefer, (2020), Xu } \\
\text { et al. (2020) }\end{array}$ \\
\hline GSK1702934A & & $\begin{array}{l}0.08 \mathrm{mM} \text { (TRPC3) } \\
0.44 \mathrm{mM} \text { (TRPC6) }\end{array}$ & Activation of TRPC $3 / 6$-currents & de la Cruz et al. (2017) \\
\hline Tonantzitlolone & & $\begin{array}{l}123 \mathrm{nM} \text { (TRPC4), } 83 \mathrm{nM} \\
\text { (TRPC5) } \\
140 \mathrm{nM} \text { (TRPC4-TRPC1), } 61 \mathrm{nM} \\
\text { (TRPC5-TRPC1) }\end{array}$ & $\begin{array}{l}\text { Against mouse fibroblasts cells, } \\
\text { human breast cancer and renal } \\
\text { cell carcinoma cells }\end{array}$ & $\begin{array}{l}\text { Pfeffer et al. (2016), Rubaiy et al. } \\
\text { (2018) }\end{array}$ \\
\hline (-)-englerin A & & $\begin{array}{l}11.2 \mathrm{nM}(\mathrm{TRPC} 4: \mathrm{C} 4) \\
7.6 \mathrm{nM}(\text { TRPC5:C5) }\end{array}$ & $\begin{array}{l}\text { Inhibit growth of various cancer } \\
\text { cell lines, breast cancers cancer } \\
\text { cells and activate PKC } \theta\end{array}$ & $\begin{array}{l}\text { Minard et al. (2018), Ratnayake } \\
\text { et al. (2009) }\end{array}$ \\
\hline BTD & oxin & $\begin{array}{l}1.3 \mu \mathrm{M} \text { (TRPC5:C5), TRPC1:C5, } \\
\text { TRPC4:C5 }\end{array}$ & Be sensitive to clemizole & Beckmann et al. (2017) \\
\hline
\end{tabular}




\section{TRPCs antagonists}

\section{TRPC3 channel}

Pyr3

Ethyl-1-(4-(2,3,3-trichloroacrylamide)phenyl)5-(trifluoromethyl)-1H-pyrazole-4-carboxylate (Pyr3) is a specific and direct inhibitor of TRPC3 channel. Pyr3 ameliorates intracerebral hemorrhage-induced brain injury and could be used as a novel treatment strategy for TRPC3-mediated diseases, including pathological cardiac remodeling and heart failure (Glasnov et al. 2009; Munakata et al. 2013). Moreover, Pyr3 exerts an inhibitory effect on the growth of human glioblastoma cancer cells and triple-negative breast cancer cells in vitro and vivo through inducing apoptosis and inhibiting migration (Chang et al. 2018; Wang et al. 2019d). The inhibitory effect of Pyr3 is dose-dependent in acute lymphoblastic leukemia cell lines (Abdoul-Azize et al. 2016). Pyr3 also inhibits smooth muscle proliferation and alleviates stent implantation-induced arterial injury (Álvarez-Miguel et al. 2017). Exposure to PM2.5 can increase the propensity to cardiac arrhythmias which could be attenuated with TRPC3 inhibition by Pyr3 (Cai et al. 2019). Pyr3 can also significantly decreases intracellular calcium concentrations, normalize resorptive activity and osteoclastic differentiation of TRPC6-deficient cells (Klein et al. 2020; Sato et al. 2020), and promotes systolic blood pressure in hypertensive patients (Hu et al. 2020d).

\section{TRPC5 channel}

\section{Galangin}

Galangin is a natural flavonoid compound from the ginger family that is used as a novel antidiabetic. It has been screened as a lanthanide-induced $\mathrm{Ca}^{2+}$ entry antagonist in overexpressed TRPC5 HEK293 cells with $\mathrm{IC}_{50}$ of $0.45 \mu \mathrm{M}$ through a screen of natural compounds in traditional Chinese medicines (Naylor et al. 2016; Brás et al. 2020). Galangin also inhibits lanthanide-induced TRPC5-mediated current and calcium entry. TRPC5 is less inhibited by other related natural flavonols, such as kaempferol and quercetin, and is not affected by myricetin, luteolin, and apigenin. Galangin can attenuate isoproterenol-induced inflammation, cardiac fibrosis, pulmonary fibrosis and non-alcoholic fatty liver disease (Thangaiyan et al. 2020; Wang et al. 2020c; Zhang et al. 2020). Galangin can also reduce cerebral ischemia-reperfusion injury by inhibiting ferroptosis and activating the SLC7A11/GPX4 axis (Guan et al. 2021). Additionally, galangin improves cardiac remodeling through the MEK1/2-ERK1/2 and PI3K-AKT pathways (Wang et al. 2019b). Differentiation of dendritic cells hows tolerogenic properties in response to lipopolysaccharide stimulation during galangin treatment (Song et al. 2021). Also, galangin has a protective effect on ulcerative colitis induced by dextran sulfate sodium in mice and rats (Sangaraju et al. 2019; Fan et al. 2021). Galangin inhibits cell growth and metastasis of cholangiocarcinoma by downregulating the expression of microRNA-21 (Zou et al. 2020). Besides, galangin inhibits epithelial-mesenchymal transition and angiogenesis of glioma by downregulating CD44 (Chen et al. 2019a). Simultaneously, galangin promotes apoptosis of diverse cancer cells, such as hepatocellular carcinoma cells, ovarian cancer cells and glioblastoma cells (Kong et al. 2019; Fang et al. 2019; Zhong et al. 2020; Huang et al. 2020). One study suggested that galangin, either alone or combined with insulin, can reduce glucose levels and improve skeletal muscle health in patients with diabetes (Kalhotra and Chittepu 2019).

\section{AC1903}

AC1903 is a specific TRPC5 inhibitor synthesized through experimentation. By comparison, AC1903 is nearly equipotent to ML204 in blocking riluzole-activated TRPC5mediated whole-cell current, but AC1903 fails to inhibit carbachol (CCh)-evoked TRPC4 and OAG-induced TRPC6 currents in whole-cell patch recordings, with a half-maximal inhibitory concentration of $14.7 \mu \mathrm{M}$ (Zhou et al. 2017). AC1903, as a TRPC5 inhibitor, can provide a therapeutic benefit to podocyte survivability in chronic kidney diseases, such as focal and segmental glomerulosclerosis (Zhou et al. 2017; van der Wijst and Bindels 2018; Sharma et al. 2019; Pablo and Greka 2019).

\section{NU6027}

NU6027 is a cyclin-dependent kinase inhibitor that inhibits the basal and zinc-augmented TRPC5 currents in TRPC5 overexpressed HEK293 cells. It has a neuroprotective effect on oxidative neuronal injury in prolonged seizures. NU6027 is considered a potent antagonist of the TRPC5 channel (Park et al. 2019). TRPC5 suppression using NU6027 reduces the neuronal death that may occur after traumatic brain injury (Park et al. 2020).

\section{TRPC6 channel}

\section{Ribemansides $A$ and $B$}

Ribemansides A and B are two new acylated $\beta$-hydroxynitrile glycosides isolated from the aerial parts of Ribes manshuricum. They can inhibit the activity of the TRPC6 channel with $\mathrm{IC}_{50}$ of 24.5 and $25.6 \mu \mathrm{M}$, respectively. These two compounds can suppress transforming growth factor $\beta 1$ 
(TGF- $\beta 1$ )-induced fibrogenesis in HK-2 cells, similar to SAR7334, a TRPC6 inhibitor (Zhou et al. 2018).

\section{Larixyl acetate}

Through testing and identifying several preparations from plant extracts, larixol and larixyl acetate were identified as TRPC6 inhibitors of receptor-induced $\mathrm{Ca}^{2+}$ entry (Urban et al. 2016). TRPC6 channel is inhibited by larixyl acetate in the DAG-stimulated rat's pulmonary artery smooth muscle cells with $\mathrm{IC}_{50}$ of 0.1-0.6 $\mu \mathrm{M}$. Larixyl acetate can also prevent hypoxia-induced pulmonary vasoconstriction (HPV) (Urban et al. 2016) and improve the endothelial function after traumatic brain injuries in mice (Chen et al. 2019b). TRPC $3 / 7$ and TRPC4/5 channels are weakly blocked by larixyl acetate, whereas no significant inhibition occurs in other related TRPV or TRPM channels (Urban et al. 2016). Moreover, larixyl acetate has analgesic and anti-inflammatory effects on neuropathic pain; therefore, it can be a novel therapy for intractable chronic pain (Wang et al. 2020b).

\section{FK506}

FK506 (Tacrolimus) is a potent immunosuppressive agent isolated from the filamentous bacteria fermentation broth, a strain of Streptomyces tsukubaensis No.9993. FK506 has been generally used in liver and kidney transplantation therapy (Kino et al. 1987; Dumont 2000; Tang et al. 2021). Studies have demonstrated that FK506 could suppress TRPC6 expression to ameliorate podocyte injury in T2DM cells (Chang et al. 2019); it also affects proteinuria and renal damage progression in renal tissues (Wei et al. 2017a; Chen et al. 2021). Down-regulation of TRPC6 by FK506 can also be used to treat overactive bladder (Chang et al. 2019). Besides, FK506-binding protein 52, as a novel interaction partner of TRPC3, improves the hypertrophic growth of cardiomyocyte cultures (Bandleon et al. 2019). Also, FK506 induces the TGF-beta 1/Smad 3 pathway to prevent intervertebral disk degeneration independent of calcineurin inhibition (Ge et al. 2020).

\section{BI 749327}

BI 749327 is an orally bioavailable TRPC6 antagonist that has been reported by Lin et al. (2019) with $\mathrm{IC}_{50}$ of $13 \mathrm{nM}$; it can boost cardiac function and ameliorate renal disease fibrosis.

\section{DS88790512}

DS88790512 is another orally bioavailable compound that is potent and a selective blocker of the TRPC6 channel; it is a icycle [4.3.0] nonane derivative with $\mathrm{IC}_{50}$ of $11 \mathrm{nM}$.
However, there have not been any reports of its efficacy in vivo (Motoyama et al. 2018) (Table 3).

\section{TRPC1/5 channels}

\section{Clemizole}

Richter et al. (2014a) identified clemizole as a novel, reversible TRPC 5 blocker that can efficiently inhibit TRPC5 currents and $\mathrm{Ca}^{2+}$ entry with $\mathrm{IC}_{50}$ ranging from 1.0 to $1.3 \mu \mathrm{M}$. In excised inside-out membrane patches, clemizole could still block TRPC5 current at single-channel level; it also affected TRPM3 and M8 and weakly impacted the TRPV1, V2, V3, and V4 channels at higher concentrations. Simultaneously, clemizole inhibits the heterologous TRPC1:C5 channel and the native TRPC5-like currents in the U-87 glioblastoma cell line. Studies have also shown that clemizole can have a certain therapeutic effect on Dravet syndrome (Strzelczyk and Schubert-Bast 2020). As a TRPC5 channel inhibitor, clemizole hydrochloride reduces electric field stimulation amplitude, which causes muscarinic receptorinduced contractions impairment of the detrusor and carotid arteries (Griffin et al. 2018; Liang et al. 2019).

\section{TRPC4/5 channels}

\section{ML204}

Through a cell-based high-throughput fluorescence assay for 305,000 compounds, ML204 has been reported as a novel, potent, and relatively selective antagonist of the TRPC4 and TRPC5 channels with $\mathrm{IC}_{50}$ of $13.6 \mu \mathrm{M}$ (Zhou et al. 2017), as well as weakly inhibiting TRPC6. ML204 has a direct inhibitory effect on TRPC $4 / 5$ channels; it also can affect other GPCR-independent receptors (Miller et al. 2011; Alom et al. 2018). ML204 can prevent pseudocyst formation; thus, podocyte numbers can be preserved by treatment with ML204 (Zhou et al. 2017). Also, ML204 reduces carotid arteries endothelium-dependent contractions in mice (Liang et al. 2019). The histamine-induced depolarization is significantly inhibited by ML204, which reduces neuronal excitation (Sato et al. 2020). Although ML204 cannot inhibit pacemaker activity, it modulates the depolarization of the membrane potential (Lee et al. 2020a). Intradermal injections of ML204 in psoriasiform skin significantly reversed chronic pruritus and the inflammation induced by imiquimod (Lee et al. 2020b). Recent studies have reported that ML204, as a selective TRPC $4 / 5$ blocker, can completely revert acetylcholine relaxations (Alom et al. 2018; Silva and Ballejo 2019). ML204 can also reduce electric-field stimulation and $\mathrm{CCh}$-evoked contractions in TRPC $4^{-1-}$ detrusor strips mice (Griffin et al. 2018). 
Table 3 TRPCs antagonists (1)

\begin{tabular}{|c|c|c|c|c|}
\hline Modulators & Chemical structure & Targeting channels and IC50 & Predicted effects & Reference \\
\hline Pyr3 & & TRPC3 & $\begin{array}{l}\text { Ameliorate severity of seizures and } \\
\text { cardiac injury, inhibit human glio- } \\
\text { blastoma cancer and melanoma cells } \\
\text { growth }\end{array}$ & $\begin{array}{l}\text { Álvarez-Miguel et al. } \\
\text { (2017), Cai et al. } \\
\text { (2019) }\end{array}$ \\
\hline Galangin & & $0.45 \mu \mathrm{M}$ (TRPC5) & $\begin{array}{l}\text { Improve ulcerative colitis; apoptosis of } \\
\text { diverse cancer cells }\end{array}$ & $\begin{array}{l}\text { Fan et al. (2021), } \\
\text { Naylor et al. (2016), } \\
\text { Zhong et al. (2020) }\end{array}$ \\
\hline AC1903 & & $14.7 \mu \mathrm{M}$ (TRPC5) & Provide chronic kidney diseases & Zhou et al. (2017) \\
\hline NU6027 & & TRPC5 & $\begin{array}{l}\text { Inhibit TRPC } 5 \text { currents, and oxidative } \\
\text { neuronal injury }\end{array}$ & Park et al. (2019) \\
\hline Ribemansides A and B & & $\begin{array}{l}24.5 \mu \mathrm{M} \text { (TRPC6, A) } \\
25.6 \mu \mathrm{M} \text { (TRPC6, B) }\end{array}$ & $\begin{array}{l}\text { Suppress TGF- } \beta 1 \text {-induced fibrogenesis } \\
\text { in HK- } 2 \text { cells }\end{array}$ & Zhou et al. (2018) \\
\hline & $\mathrm{A}: \mathrm{R}=\mathrm{H} \mathrm{B}: \mathrm{R}=\mathrm{OCH}$ & & & \\
\hline larixyl acetate & & $0.1-0.6 \mu \mathrm{M}$ (TRPC6) & $\begin{array}{l}\text { Prevent HPV, improved traumatic brain } \\
\text { injuries }\end{array}$ & Urban et al. (2016) \\
\hline FK-506 & & TRPC6 & Ameliorate liver and renal damage & Chang et al. (2019) \\
\hline BI 749327 & & $13 \mathrm{nM}$ (TRPC6) & $\begin{array}{l}\text { Support cardiac function and renal } \\
\text { disease }\end{array}$ & Lin et al. (2019) \\
\hline DS88790512 & & $11 \mathrm{nM}$ (TRPC6) & Inhibit TRPC6 channel & Motoyama et al. (2018) \\
\hline
\end{tabular}

\section{M084}

M084 is a 2-aminobenzimidazole derivative similar to ML204 reported to effectively block the TRPC4 and TRPC5 channels with $\mathrm{IC}_{50}$ of 10.3 and $8.2 \mu \mathrm{M}$, respectively. On the other hand, M084 weakly inhibits TRPC3 and moderately inhibits TRPC6 (Zhu et al. 2015). Research has discovered that M084 also has antidepressant and anti-anxiety effects in mice experiments (Yang et al. 2015). Additionally, Zhu et al. (2015) proved that M084 effectively inhibits the plateau potential induced by TRPC4-containing channels through electrophysiological recording in the lateral septal neurons of mice. Through synthesizing and testing a total of 28 structural analogs of M084, it has been found that the 2-aminobenzimidazol skeleton is an essential requirement for blocking the TRPC4 channel (Zhu et al. 2015).

\section{AM12}

Based on structure-activity relationship studies of the stated natural and other synthetic flavonols, 3,5,7-trihydroxy-2-(2bromophenyl)-4H-chromen-4-one (AM12) was designed.
AM12 can directly inhibit the activation of lanthanideinduced and (-)-englerin A -evoked TRPC5 channel with $\mathrm{IC}_{50}$ of $0.28 \mu \mathrm{M}$. Likewise, it inhibits TRPC4 channels and weakly inhibits the TRPC1-TRPC5 channel (Naylor et al. 2016).

\section{TRPC3/6 channels}

\section{Salvianolic acid B}

Salvianolic acid B, extracted from the root of Salvia miltiorrhiza Bunge (Lamiaceae), is the most abundant bioactive compound that inhibits the expression of TRPC 3 and TRPC6 channels. In the cardiovascular system, salvianolic acid B effectively counteracts doxorubicin (DOX)-evoked structural heart abnormalities and apoptotic damage, and inhibits the DOX-induced $\mathrm{Ca}^{2+}$ overload and endoplasmic reticulum stress in cardiomyocytes via TRPC3 and TRPC6 inhibition (Chen et al. 2017; Li et al. 2020a). Salvianolic acid B can also alleviate myocardial ischemic injury by inhibiting activation of the NLRP3 inflammasome and promoting mitophagy (Hu et al. 2020c). Regarding its effects 
on the hepatic system, salvianolic acid B suppresses hepatic endoplasmic reticulum stress to improve insulin resistance in ob/ob mice (Shi et al. 2020). Salvianolic acid B also blocks the activation of hepatic stellate cells, protects against sepsis-induced liver injury, and prevents and alleviates liver, pulmonary and renal interstitial fibrosis (Su et al. 2020; Ma et al. 2020; Jiang et al. 2020a; Hu et al. 2020b; Tian et al. 2021; Gong et al. 2021). Furthermore, salvianolic acid B prevents high-fat diet-induced obese mice body weight gain and regulates gut microbiota ( $\mathrm{Li}$ et al. 2020b). Additionally, salvianolic acid B decreases mice interleukin-1 betainduced colitis recurrence (Feng et al. 2020). Ragarding its effects on the skeletal system, salvianolic acid B promotes new bone formation and protects against oxidative damage (Kayalar et al. 2020; Xiao et al. 2020; Bian and Xiang 2020); it improves atherosclerosis by inhibiting the YAP/TAZ/JNK signaling pathway in endothelial cells and pericytes (Yang et al. 2020). In the nervous system, salvianolic acid B could improve the cognitive impairment of mice infected with Porphyromonas gingivalis by inhibiting neuroinflammation and reducing A $\beta$ level (Liu et al. 2020). Salvianolic acid B can also improve chronic mild stress-induced depressive behaviors in rats via the AMPK/SIRT1 signaling pathway (Liao et al. 2020). As an otoprotective agent, salvianolic acid B inhibits ototoxic drug-induced ototoxicity by suppressing the apoptosis pathway (Zheng et al. 2020).

\section{$\operatorname{Rox} 4560$}

Rox 4560 is a TRPC $3 / 6$ channel antagonist that could suppress the elevation of thrombin intracellular calcium levels in podocytes (Guan et al. 2017).

\section{TRPC1/6 channels}

\section{Sildenafil}

Sildenafil inhibits TRPC1 and TRPC6 expressions through PPAR $\gamma$-dependent mechanisms counteracting podocyte injury and proteinuria (Sonneveld et al. 2017). Sildenafil also has potential cardioprotective effects (Santiago-Vacas et al. 2021).

\section{TRPC1/4/5 channels}

\section{Picol45}

Pico145 (C31, HC-608) is a xanthine derivative that potently inhibits TRPC $1 / 4 / 5$ channels with $\mathrm{IC}_{50}$ of $1.3 \mathrm{nM}$ (TRPC5:C5), $0.349 \mathrm{nM}$ (TRPC4:C4), $0.199 \mathrm{nM}$ (TRPC5:C1, heteromers), and 0.033 nM (TRPC4:C1, heteromers) (Rubaiy et al. 2017b). Pico145 can directly, reversibly, and competitively inhibits the AM237-mediated
TRPC5:C5 channel activation (Rubaiy et al. 2017a; Minard et al. 2019; Wright et al. 2020). The potency of Pico145 depends on the concentration of the (-)-englerin A (Rubaiy et al. 2017b). Pico145 was also found to be highly similar to HC-070 (Just et al. 2018). Inhibition of TRPC1 by Pico145 causes group I metabotropic glutamate receptors-induced long-term depression and memory extinction in mice (Yerna et al. 2020). Additionally, Pico145 can prevent adverse reactions of the cancer cell cytotoxic agent (-)-englerin A (Cheung et al. 2018).

\section{HCO70}

HC070 is a highly potent, small molecule antagonist of TRPC4 and TRPC5 invented by Just et al. (Just et al. 2018). HC070 inhibits the homologous TRPC4:C4 $\left(\mathrm{IC}_{50}=46.0 \mathrm{nM}\right)$ and TRPC $5: \mathrm{C} 5\left(\mathrm{IC}_{50}=0.52 \mathrm{nM}\right)$ channel, as well as the heterologous TRPC1:C5 $\left(\mathrm{IC}_{50}=1.4 \mathrm{nM}\right.$, $\mathrm{La}^{3+}$-activated; $\mathrm{IC}_{50}=4.4 \mathrm{nM}, \mathrm{M} 1$ receptor-activated), and TRPC1:C4 $\left(\mathrm{IC}_{50}=1.3 \mathrm{nM}\right)$ channel. $\mathrm{HC} 070$ also reversibly inhibits the lanthanum-induced mouse TRPC5 current with $\mathrm{IC}_{50}$ of $0.55 \mathrm{nM}$. Additionally, HC070 and Pico145 showed anxiolytic and antidepressant effects on mice (Just et al. 2018; Rubaiy 2019).

\section{TRPC3/6/7 channels}

\section{SAR7334}

SAR7334 is a novel, highly potent, and bioavailable compound that inhibits TRPC6-, TRPC3-, and TRPC7-induced $\mathrm{Ca}^{2+}$ influx with $\mathrm{IC}_{50}$ of $9.5,282$, and $226 \mathrm{nM}$, respectively, whereas it does not affect TRPC4/5 channels (Maier et al. 2015). Furthermore, SAR7334 suppresses TRPC6dependent acute HPV in the isolated perfused lungs of mice (Maier et al. 2015) and (O-3)-induced airway inflammatory responses (Chen et al. 2020a). SAR7334 can also negate malignant hyperthermia hypersensitivity by blocking TRPC3/6 (Lopez et al. 2020a). There is a strong possibility that SAR7334 improves cognitive deficits (Uryash et al. 2020). As for the cardiovascular system, SAR7334 dosedependently attenuates systolic and diastolic blood pressure variability (Wang et al. 2020d). Additionally, TRPC6 knockdown by SAR7334 inhibits renal tubular epithelial cells apoptosis upon oxidative stress through autophagy activation (Hou et al. 2018).

\section{Compound $14 a$}

Compound 14a is a novel TRPC6 antagonist that strongly inhibits 4o, TRPC $3 / 6 / 7$ agonist-induced, and receptoroperated activation of the TRPC6 channel. Compound 14a inhibits TRPC 3/6/7 (TRPC6 $>$ C7 $>$ C3) with $\mathrm{IC}_{50}$ of around 
$1 \mu \mathrm{M}$ against gastric cancer cell growth and xenograft tumor formation. Compound 14a weakly affects the TRPC4 channel and doesn't affect other TRP channels (Ding et al. 2018).

\section{TRPC3/5/6 channels}

\section{$K B-R 7943$}

Whole-cell voltage-clamp experiments confirmed that KB-R7943 could potently block TRPC3, TRPC6, and TRPC5 currents with $\mathrm{IC}_{50}$ of $0.46,0.71,1.38 \mu \mathrm{M}$, respectively, and nearly fully suppress the OAG-induced $\mathrm{Ca}^{2+}$ entry in HEK293 cells (Kraft 2007) (Table 4).

\section{Nonselective TRPCs}

\section{SKF96365}

Merritt et al. (1990) originally identified SKF96365 as a novel inhibitor of ROCE, (1-( $\beta$-[3-(4-methoxy-phenyl) propoxy]-4-methoxyphen-ethyl)-1 H-imidazole hydrochloride), with $\mathrm{IC}_{50}$ of around $10 \mu \mathrm{M}$. However, SKF96365 was not as potent or selective as desired because it could also block T-type calcium channels (Singh et al. 2010). A previous study indicated that SKF96365 inhibits TRPC channels, arrests the cell cycle in the G2/M phase, and suppresses cell growth in AGS or MKN45 human gastric cancer cell lines

Table 4 TRPCs antagonists (2)

\begin{tabular}{|c|c|c|c|c|}
\hline Modulators & Chemical structure & Targeting channels and IC50 & Predicted effects & Reference \\
\hline Clemizole & & $\begin{array}{l}\text { 1.0-1.3 } \mu \mathrm{M}(\mathrm{TRPC} 5) \\
\mathrm{TRPC} 1: \mathrm{C} 5\end{array}$ & $\begin{array}{l}\text { Inhibit TRPC1:C5 channel and } \\
\text { TRPC5 currents in the U-87 } \\
\text { glioblastoma cell line }\end{array}$ & Richter et al. (2014a) \\
\hline ML204 & & $13.6 \mu \mathrm{M}(\mathrm{TRPC} 4 / 5)$ & $\begin{array}{l}\text { Block riluzole-activated } \\
\text { TRPC5-mediated current; } \\
\text { reduce the mouse carotid } \\
\text { arteries endothelium-depend- } \\
\text { ent contractions }\end{array}$ & $\begin{array}{l}\text { Liang et al. (2019), Miller et al. } \\
\text { (2011), Zhou et al. (2017) }\end{array}$ \\
\hline M084 & & $\begin{array}{l}10.3 \mu \mathrm{M} \text { (TRPC4), } 8.2 \mu \mathrm{M} \\
\quad \text { (TRPC5) }\end{array}$ & $\begin{array}{l}\text { Antidepressant and anti-anxiety } \\
\text { effects }\end{array}$ & $\begin{array}{l}\text { Yang et al. (2015), Zhu et al. } \\
\text { (2015) }\end{array}$ \\
\hline AM12 & & $\begin{array}{l}0.28 \mu \mathrm{M}(\mathrm{TRPC} 5) \\
\mathrm{TRPC} 4\end{array}$ & $\begin{array}{l}\text { Inhibit the activation TRPC5 } \\
\text { channel }\end{array}$ & Naylor et al. (2016) \\
\hline Salvianolic acid B & & TRPC3, TRPC6 & $\begin{array}{l}\text { Counteracted DOX-evoked heart } \\
\text { abnormalities and tissue injury }\end{array}$ & $\begin{array}{l}\text { Chen et al. (2017), Su et al. } \\
\text { (2020) }\end{array}$ \\
\hline Rox 4560 & & TRPC3/6 & $\begin{array}{l}\text { Suppress calcium levels in } \\
\text { podocytes }\end{array}$ & Guan et al. (2017) \\
\hline Sildenafil & & TRPC1/6 & $\begin{array}{l}\text { Counteracting renal injury; } \\
\text { cardioprotective effects }\end{array}$ & $\begin{array}{l}\text { Lu et al. (2010), Santiago-Vacas } \\
\text { et al. (2021), Sonneveld et al. } \\
\text { (2017) }\end{array}$ \\
\hline Pico145 & & $\begin{array}{l}1.3 \mathrm{nM}(\mathrm{TRPC} 5: \mathrm{C} 5), 0.349 \mathrm{nM} \\
\quad(\mathrm{TRPC} 4: \mathrm{C} 4) \\
0.199 \mathrm{nM}(\mathrm{TRPC} 5: \mathrm{C} 1) \\
0.033 \mathrm{nM}(\mathrm{TRPC} 4: \mathrm{C} 1)\end{array}$ & $\begin{array}{l}\text { Inhibit AM237-mediated } \\
\text { TRPC5:C5 channel activation }\end{array}$ & $\begin{array}{l}\text { Minard et al. (2019), Rubaiy et al. } \\
\quad(2017 \mathrm{a}, \mathrm{b})\end{array}$ \\
\hline HC070 & & $\begin{array}{l}46.0 \mathrm{nM}(\mathrm{TRPC} 4: \mathrm{C} 4), 0.52 \mathrm{nM} \\
\quad(\mathrm{TRPC} 5: \mathrm{C} 5) \\
1.4 \mathrm{nM}(\mathrm{TRPC} 1: \mathrm{C} 5), 1.3 \mathrm{nM} \\
\text { (TRPC1:C4) }\end{array}$ & Anxiolytic and anti-depressant & Just et al. (2018) \\
\hline SAR7334 & & $\begin{array}{l}9.5 \mathrm{nM} \text { (TRPC6), } 282 \mathrm{nM} \\
\text { (TRPC3) } \\
226 \mathrm{nM} \text { (TRPC7) }\end{array}$ & $\begin{array}{l}\text { Suppress acute HPV; attenuate } \\
\text { renal injury }\end{array}$ & $\begin{array}{l}\text { Hou et al. (2018), Maier et al. } \\
\text { (2015) }\end{array}$ \\
\hline Compound 14a & & $\sim 1 \mu \mathrm{M}(\mathrm{TRPC} 3 / 6 / 7)$ & $\begin{array}{l}\text { Inhibit gastric cancer cell } \\
\text { growth }\end{array}$ & Ding et al. (2018) \\
\hline KB-R7943 & & $\begin{array}{l}0.46 \mu \mathrm{M} \text { (TRPC3), } 0.71 \mu \mathrm{M} \\
\quad(\mathrm{TRPC} 6) \\
1.38 \mu \mathrm{M} \text { (TRPC5) }\end{array}$ & Suppress $\mathrm{Ca}^{2+}$ entry & Kraft (2007) \\
\hline
\end{tabular}


(Ge et al. 2018), as well as arresting the cell cycle in the $\mathrm{S}$ and G2 phases in glioblastoma cells (Song et al. 2014). SKF96365 is proven effective in the therapy of primary thermal and mechanical hyperalgesia and persistent spontaneous nociception (Ding et al. 2011, 2012). As a SOCE inhibitor, SKF-96365 also exhibits potent anti-neoplastic activity in non-small cell lung cancer cells (Wang et al. 2018b). Moreover, recent reports showed evidence that SKF-96365 induces reduction in cardiac conduction (He et al. 2017). Moreover, SKF96365 reduces $\mathrm{Ca}^{2+}$ concentration and airway smooth muscle cell viability in asthmatic mice (Zhang et al. 2018a).

\section{$2-A P B$}

2-Aminoethoxydiphenyl borate (2-APB) is an inositol 1,4,5-trisphosphate receptors (IP3Rs) antagonist and TRPC channel antagonist that blocks the expression of human TRPC5 and TRPC6 in HEK-293 cells. In the concentration-response curve, 2-APB has $\mathrm{IC}_{50}$ of $20 \mu \mathrm{M}$ (Diver et al. 2001; Xu et al. 2005; Sekaran et al. 2007). 2-APB can act directly on TRPC ion channels in melanopsin-expressing ganglion cells (Sekaran et al. 2007). TRPC1/3/6 inhibition by SKF96365 and 2-APB attenuates TGF- $\beta 1$-induced epithelial-mesenchymal transition in gastric cancer via the Ras/Raf1/ERK signaling pathway (Ge et al. 2018) (Table 5).

All nonselective TRPCs antagonists have certain inhibitory effects on various cell types and can target a particular channel or disease through structural modification, which presents a novel TRPCs therapeutic target for drug discovery.

\section{Discussion}

TRPCs are associated with the occurrence and development of many diseases. Studies have proved that they are linked with different crucial roles in the pathophysiological process of many diseases; thus, they present a novel target for the intervention and treatment of some diseases. Additionally, the emergence of TRPCs modulators can prompt an understanding of these channels in health and disease.

At present, highly potent and highly selective TRPCs modulators, such as (-)-englerin A, hyperforin, ML204, Pico145, HC070, Pyr3, DS88790512, and AC1903 are still unprecedented opportunities for TRPCs research. However, some obstacles, such as the toxicity and instability of (-)-englerin A in the cardiac and respiratory systems limit their use (Wu et al. 2017b; Minard et al. 2018; Rubaiy 2019). Additionally, hyperforin is also unstable and susceptible to oxygen, heat, and light. Pico145 and HC070 are suitable for in vivo studies, whereas ML204 and DS88790512 were only conducted in vitro studies; thus, there are no reports on their in vivo efficacy. AC1903 could cause a developmental defect in the amygdala. These problems are collectively obstructive to the usage of the current selective TRPCs modulators; thus, the development of new TRPCs modulators drugs that are more potent and more selective is needed.

With the tremendous advancement of science and drug technologies, discovering the means to overcome the mentioned undesired effects becomes possible. In structural biology, high-resolution structures are increasingly becoming the dominant method for determining the structures of many receptor complexes through cryo-EM technology. In recent decades, rich combinatorial compound libraries provide an abundant material basis for high-throughput screening due to their vast quantities and diverse structures that have become a popular approach to discovering and developing new medications, offering possibilities for finding suitable TRPCs modulators. Furthermore, many reports revealed that antisense oligonucleotide therapies and small molecule peptides therapies have increasingly become a novel strategy for treating a variety of diseases (Yamamoto et al. 2016; Beekman and Howell 2016; Mignani et al. 2019; Chen et al. 2020b; Tahirovic et al. 2020). Studying channel domains functions, especially the precise interpretation of modulators' binding sites, helps discover highly selective TRPCs

Table 5 TRPCs antagonists (3)

\begin{tabular}{|c|c|c|c|c|}
\hline Modulators & Chemical structure & Targeting channels and IC50 & Predicted effects & Reference \\
\hline SKF96365 & & $\begin{array}{l}\text { TRPC, low-voltage- } \\
\text { activated T-type calcium } \\
\text { channels } \\
10 \mu \mathrm{M}\end{array}$ & $\begin{array}{l}\text { suppress growth in human gastric cancer cell lines, } \\
\text { glioblastoma cells, non-small cell lung cancer } \\
\text { and colorectal cancer cells, primary thermal and } \\
\text { mechanical hyperalgesia and persistent spontane- } \\
\text { ous nociception, induce a reduction in cardiac } \\
\text { condition }\end{array}$ & $\begin{array}{l}\text { Ding et al. (2011), Singh } \\
\text { et al. (2010), Song } \\
\text { et al. (2014), Ge et al. } \\
\text { (2018) }\end{array}$ \\
\hline 2-APB & & $\begin{array}{l}\text { TRPC, TRPM3 } \\
20 \mu \mathrm{M}\end{array}$ & $\begin{array}{l}\text { Act directly on a TRPC ion channel in melanopsin- } \\
\text { expressing ganglion cells, block human TRPC5, } \\
\text { TRPC6 and TRPM3 channels }\end{array}$ & $\begin{array}{l}\text { Diver et al. (2001), Ge } \\
\text { et al. (2018), Sekaran } \\
\text { et al. (2007), Xu et al. } \\
\text { (2005) }\end{array}$ \\
\hline
\end{tabular}


modulators. These new technologies permit a more comprehensive assessment of the structures and function of TRPCs in physiology and pathophysiology, thereby providing the means to find more potent and selective TRPCs modulators.

Acknowledgements The present work was supported by the National Natural Science Foundation of China Nos. 81770432, 81970245 to X. Q. Li., and the Innovation Capacity Support Project of Shaanxi Province in China No. 2019PT-23 to X. Q. Li.

\section{Compliance with ethical standards}

Conflict of interest The authors declare no conflict of interest.

\section{References}

Abdoul-Azize S, Buquet C, Vannier JP, Dubus I (2016) Pyr3, a TRPC3 channel blocker, potentiates dexamethasone sensitivity and apoptosis in acute lymphoblastic leukemia cells by disturbing $\mathrm{Ca}^{2+}$ signaling, mitochondrial membrane potential changes and reactive oxygen species production. Eur J Pharmacol 784:90-98. https://doi.org/10.1016/j.ejphar.2016.05.014

Agip AA, Blaza JN, Fedor JG, Hirst J (2019) Mammalian respiratory complex I through the lens of cryo-EM. Annu Rev Biophys 48:165-184. https://doi.org/10.1146/annurev-bioph ys-052118-115704

Akbulut Y, Gaunt HJ, Muraki K, Ludlow MJ, Amer MS, Bruns A, Vasudev NS, Radtke L, Willot M, Hahn S, Seitz T, Ziegler S, Christmann M, Beech DJ, Waldmann H (2015) (-)-Englerin A is a potent and selective activator of TRPC4 and TRPC5 calcium channels. Angew Chem Int Ed Engl 54:3787-3791. https://doi. org/10.1002/anie.201411511

Allegra A, Tonacci A (2020) Antiproliferative effects of St. John's Wort, its derivatives, and other hypericum species in hematologic malignancies. Int J Mol Sci. https://doi.org/10.3390/ijms2 2010146

Alom F, Miyakawa M, Matsuyama H, Nagano H, Tanahashi Y, Unno T (2018) Possible antagonistic effects of the TRPC4 channel blocker ML204 on M2 and M3 muscarinic receptors in mouse ileal and detrusor smooth muscles and atrial myocardium. J Vet Med Sci 80:1407-1415. https://doi.org/10.1292/jvms.18-0197

Álvarez-Miguel I, Cidad P, Pérez-García MT (2017) Differences in TRPC 3 and TRPC6 channels assembly in mesenteric vascular smooth muscle cells in essential hypertension. J Physiol 595:1497-1513. https://doi.org/10.1113/jp273327

Augustin Y, Staines HM, Krishna S (2020) Artemisinins as a novel anti-cancer therapy: targeting a global cancer pandemic through drug repurposing. Pharmacol Ther 216:107706. https://doi.org/ 10.1016/j.pharmthera.2020.107706

Aydar E, Yeo S, Djamgoz M, Palmer C (2009) Abnormal expression, localization and interaction of canonical transient receptor potential ion channels in human breast cancer cell lines and tissues: a potential target for breast cancer diagnosis and therapy. Cancer Cell Int 9:23. https://doi.org/10.1186/1475-2867-9-23

Azumaya CM, Sierra-Valdez F, Cordero-Morales JF, Nakagawa T (2018) Cryo-EM structure of the cytoplasmic domain of murine transient receptor potential cation channel subfamily $\mathrm{C}$ member 6 (TRPC6). J Biol Chem 293:10381-10391. https://doi.org/10. 1074/jbc.RA118.003183

Bai G, Gao Y, Liu S, Shui S, Liu G (2020) pH-dependent rearrangement determines the iron-activation and antitumor activity of artemisinins. Free Radic Biol Med 163:234-242. https://doi.org/ 10.1016/j.freeradbiomed.2020.12.024

Baltin ME, Sabirova DE, Kiseleva EI, Kamalov MI, Abdullin TI, Petrova NV, Ahmetov NF, Sachenkov OA, Baltina TV, Lavrov IA (2021) Comparison of systemic and localized carrier-mediated delivery of methylprednisolone succinate for treatment of acute spinal cord injury. Exp Brain Res. https://doi.org/10.1007/ s00221-020-05974-w

Bandleon S, Strunz PP, Pickel S, Tiapko O, Cellini A, Miranda-Laferte E, Eder-Negrin P (2019) FKBP52 regulates TRPC3-dependent $\mathrm{Ca}^{2+}$ signals and the hypertrophic growth of cardiomyocyte cultures. J Cell Sci. https://doi.org/10.1242/jcs.231506

Basora N, Boulay G, Bilodeau L, Rousseau E, Payet MD (2003) 20-hydroxyeicosatetraenoic acid (20-HETE) activates mouse TRPC6 channels expressed in HEK293 cells. J Biol Chem 278:31709-31716. https://doi.org/10.1074/jbc.M304437200

Batova A, Altomare D, Creek KE, Naviaux RK, Wang L, Li K, Green E, Williams R, Naviaux JC, Diccianni M, Yu AL (2017) Englerin A induces an acute inflammatory response and reveals lipid metabolism and ER stress as targetable vulnerabilities in renal cell carcinoma. PLoS ONE 12:e0172632. https://doi.org/10. 1371/journal.pone.0172632

Beekman AM, Howell LA (2016) Small-molecule and peptide inhibitors of the pro-survival protein Mcl-1. ChemMedChem 11:802813. https://doi.org/10.1002/cmdc.201500497

Beckmann H, Richter J, Hill K, Urban N, Lemoine H, Schaefer M (2017) A benzothiadiazine derivative and methylprednisolone are novel and selective activators of transient receptor potential canonical 5 (TRPC5) channels. Cell Calcium 66:10-18. https:// doi.org/10.1016/j.ceca.2017.05.012

Bian Y, Xiang J (2020) Salvianolic acid B promotes the osteogenic differentiation of human periodontal ligament cells through Wnt/ $\beta$ catenin signaling pathway. Arch Oral Biol 113:104693. https:// doi.org/10.1016/j.archoralbio.2020.104693

Billion E, Hadchouel A, Garcelon N, Delacourt C, Drummond D (2021) Intravenous pulses of methylprednisolone for infants with severe bronchopulmonary dysplasia and respiratory support after 3 months of age. Pediatr Pulmonol 56:74-82. https://doi.org/10. 1002/ppul.25109

Boulay G, Zhu X, Peyton M, Jiang M, Hurst R, Stefani E, Birnbaumer L (1997) Cloning and expression of a novel mammalian homolog of Drosophila transient receptor potential (Trp) involved in calcium entry secondary to activation of receptors coupled by the Gq class of G protein. J Biol Chem 272:29672-29680. https:// doi.org/10.1074/jbc.272.47.29672

Brás NF, Neves RPP, Lopes FAA, Correia MAS, Palma AS, Sousa SF, Ramos MJ (2020) Combined in silico and in vitro studies to identify novel antidiabetic flavonoids targeting glycogen phosphorylase. Bioorg Chem. https://doi.org/10.1016/j.bioorg.2020.104552

Busch T, Drager G, Kunst E, Benson H, Sasse F, Siems K, Kirschning A (2016) Synthesis and antiproliferative activity of new tonantzitlolone-derived diterpene derivatives. Org Biomol Chem 14:9040-9045. https://doi.org/10.1039/c6ob01697a

Cai C, Huang J, Lin Y, Miao W, Chen P, Chen X, Wang J, Chen M (2019) Particulate matter 2.5 induced arrhythmogenesis mediated by TRPC 3 in human induced pluripotent stem cell-derived cardiomyocytes. Arch Toxicol 93:1009-1020. https://doi.org/10. 1007/s00204-019-02403-y

Camacho Londoño JE, Tian Q, Hammer K, Schröder L, Camacho Londoño J, Reil JC, He T, Oberhofer M, Mannebach S, Mathar I, Philipp SE, Tabellion W, Schweda F, Dietrich A, Kaestner L, Laufs U, Birnbaumer L, Flockerzi V, Freichel M, Lipp P (2015) A background $\mathrm{Ca}^{2+}$ entry pathway mediated by TRPC1/TRPC4 is critical for development of pathological cardiac remodelling. Eur Heart J 36:2257-2266. https://doi.org/10.1093/eurheartj/ ehv250 
Chang HH, Cheng YC, Tsai WC, Tsao MJ, Chen Y (2018) Pyr3 induces apoptosis and inhibits migration in human glioblastoma cells. Cell Physiol Biochem 48:1694-1702. https://doi.org/10. $1159 / 000492293$

Chang C, Li K, Jiang S, Li B, Cao L, Wang P (2019) Downregulation of TRPC6 expression is a critical molecular event during FK506 treatment for overactive bladder. Cell Calcium 77:8-19. https:// doi.org/10.1016/j.ceca.2018.11.007

Chen X, Wang DD, Li ZP (2021) Analysis of time course and dose effect of tacrolimus on proteinuria in lupus nephritis patients. $\mathbf{J}$ Clin Pharm Ther 46:106-113. https://doi.org/10.1111/jcpt.13260

Chen RC, Sun GB, Ye JX, Wang J, Zhang MD, Sun XB (2017) Salvianolic acid $B$ attenuates doxorubicin-induced ER stress by inhibiting TRPC3 and TRPC6 mediated $\mathrm{Ca}^{2+}$ overload in rat cardiomyocytes. Toxicol Lett 276:21-30. https://doi.org/10. 1016/j.toxlet.2017.04.010

Chen WT, Chen YK, Lin SS, Hsu FT (2018) Hyperforin suppresses tumor growth and NF- $\mathrm{KB}$-mediated anti-apoptotic and invasive potential of non-small cell lung cancer. Anticancer Res 38:21612167. https://doi.org/10.21873/anticanres. 12457

Chen D, Li D, Xu XB, Qiu S, Luo S, Qiu E, Rong Z, Zhang J, Zheng D (2019a) Galangin inhibits epithelial-mesenchymal transition and angiogenesis by downregulating CD44 in glioma. J Cancer 10:4499-4508. https://doi.org/10.7150/jca.31487

Chen X, Taylor-Nguyen NN, Riley AM, Herring BP, White FA, Obukhov AG (2019b) The TRPC6 inhibitor, larixyl acetate, is effective in protecting against traumatic brain injury-induced systemic endothelial dysfunction. J Neuroinflammation 16:21. https://doi. org/10.1186/s12974-019-1407-6

Chen QZ, Zhou YB, Zhou LF, Fu ZD, Yang CT, Zhao L, Li SN, Chen Y, Wu YS, Ling ZW, Wang YF, Huang JR, Li JH (2020a) TRPC6-dependent $\mathrm{Ca}^{2+}$ signaling mediates airway inflammation in response to oxidative stress via ERK pathway. Cell Death Dis 11:16. https://doi.org/10.1038/s41419-020-2360-0

Chen X, Tang WJ, Shi JB, Liu MM, Liu XH (2020b) Therapeutic strategies for targeting telomerase in cancer. Med Res Rev 40:532585. https://doi.org/10.1002/med.21626

Cheung SY, Henrot M, Al-Saad M, Baumann M, Muller H, Unger A, Rubaiy HN, Mathar I, Dinkel K, Nussbaumer P, Klebl B, Freichel M, Rode B, Trainor S, Clapcote SJ, Christmann M, Waldmann H, Abbas SK, Beech DJ, Vasudev NS (2018) TRPC4/ TRPC 5 channels mediate adverse reaction to the cancer cell cytotoxic agent (-)-englerin A. Oncotarget 9:29634-29643. https:// doi.org/10.18632/oncotarget.25659

Cortez I, Hernandez CM, Dineley KT (2020) Enhancement of select cognitive domains with rosiglitazone implicates dorsal hippocampus circuitry sensitive to PPARgamma agonism in an Alzheimer's mouse model. Brain Behav. https://doi.org/10.1002/ brb3.1973

Cosens DJ, Manning A (1969) Abnormal electroretinogram from a Drosophila mutant. Nature 224:285-287. https://doi.org/10. 1038/224285a0

de la Cruz GG, Svobodova B, Lichtenegger M, Tiapko O, Groschner $\mathrm{K}$, Glasnov T (2017) Intensified microwave-assisted N-acylation procedure - synthesis and activity evaluation of TRPC 3 channel agonists with a 1,3-dihydro-2H-benzo[d]imidazol-2-one core. Synlett 28:695-700. https://doi.org/10.1055/s-0036-1589472

Ding J, Xiao Y, Lu D, Du YR, Cui XY, Chen J (2011) Effects of SKF96365, a TRPC inhibitor, on melittin-induced inward current and intracellular $\mathrm{Ca}^{2+}$ rise in primary sensory cells. Neurosci Bull 27:135-142. https://doi.org/10.1007/s12264-011-1018-4

Ding J, Zhang JR, Wang Y, Li CL, Lu D, Guan SM, Chen J (2012) Effects of a non-selective TRPC channel blocker, SKF-96365, on melittin-induced spontaneous persistent nociception and inflammatory pain hypersensitivity. Neurosci Bull 28:173-181. https:// doi.org/10.1007/s12264-012-1213-y
Ding M, Wang H, Qu C, Xu F, Zhu Y, Lv G, Lu Y, Zhou Q, Zhou H, Zeng X, Zhang J, Yan C, Lin J, Luo HR, Deng Z, Xiao Y, Tian J, Zhu MX, Hong X (2018) Pyrazolo[1,5-a]pyrimidine TRPC6 antagonists for the treatment of gastric cancer. Cancer Lett 432:47-55. https://doi.org/10.1016/j.canlet.2018.05.041

Diver JM, Sage SO, Rosado JA (2001) The inositol trisphosphate receptor antagonist 2-aminoethoxydiphenylborate (2-APB) blocks $\mathrm{Ca}^{2+}$ entry channels in human platelets: cautions for its use in studying $\mathrm{Ca}^{2+}$ influx. Cell Calcium 30:323-329. https:// doi.org/10.1054/ceca.2001.0239

Doleschal B, Primessnig U, Wölkart G, Wolf S, Schernthaner M, Lichtenegger M, Glasnov TN, Kappe CO, Mayer B, Antoons G, Heinzel F, Poteser M, Groschner K (2015) TRPC3 contributes to regulation of cardiac contractility and arrhythmogenesis by dynamic interaction with NCX1. Cardiovasc Res 106:163-173. https://doi.org/10.1093/cvr/cvv022

Dryer SE, Roshanravan H, Kim EY (2019) TRPC channels: regulation, dysregulation and contributions to chronic kidney disease. Biochim Biophys Acta Mol Basis Dis 1865:1041-1066. https:// doi.org/10.1016/j.bbadis.2019.04.001

Duan J, Li J, Zeng B, Chen GL, Peng X, Zhang Y, Wang J, Clapham DE, Li Z, Zhang J (2018) Structure of the mouse TRPC4 ion channel. Nat Commun 9:3102. https://doi.org/10.1038/ s41467-018-05247-9

Duan J, Li J, Chen GL, Ge Y, Liu J, Xie K, Peng X, Zhou W, Zhong J, Zhang Y, Xu J, Xue C, Liang B, Zhu L, Liu W, Zhang C, Tian XL, Wang J, Clapham DE, Zeng B, Li Z, Zhang J (2019) Cryo-EM structure of TRPC5 at 2.8-A resolution reveals unique and conserved structural elements essential for channel function. Sci Adv 5:eaaw7935. https://doi.org/10.1126/ sciadv.aaw7935

Dumont FJ (2000) FK506, an immunosuppressant targeting calcineurin function. Curr Med Chem 7:731-748. https://doi.org/10.2174/ 0929867003374723

Ebrey RJ (1999) Antibacterial activity of hyperforin from St John's wort. Lancet 354:777. https://doi.org/10.1016/s0140-6736(05) 76020-7

Egelman EH (2016) The current revolution in cryo-EM. Biophys J 110:1008-1012. https://doi.org/10.1016/j.bpj.2016.02.001

Falcon D, Galeano-Otero I, Martin-Bornez M, Fernandez-Velasco M, Gallardo-Castillo I, Rosado JA, Ordonez A, Smani T (2020) TRPC channels: dysregulation and $\mathrm{Ca}^{2+}$ mishandling in ischemic heart disease. Cells. https://doi.org/10.3390/cells9010173

Fan C, Choi W, Sun W, Du J, Lu W (2018) Structure of the human lipid-gated cation channel TRPC3. Elife. https://doi.org/10.7554/ eLife.36852

Fan J, Zhao XH, Li TJ (2021) Heat treatment of galangin and kaempferol inhibits their benefits to improve barrier function in rat intestinal epithelial cells. J Nutr Biochem 87:108517. https:// doi.org/10.1016/j.jnutbio.2020.108517

Fang D, Xiong Z, Xu J, Yin J, Luo R (2019) Chemopreventive mechanisms of galangin against hepatocellular carcinoma: a review. Biomed Pharmacother 109:2054-2061. https://doi.org/10.1016/j. biopha.2018.09.154

Feng PP, Fang XS, Zhao SH, Fu JY, Zhang HT, Yi YL, Li CY, Jiang CL, Chen DP (2020) Salvianolic acid B decreases interleukin-1 beta-induced colitis recurrence in mice. Chin Med J 133:14361444. https://doi.org/10.1097/cm9.0000000000000773

Foster RR, Zadeh MA, Welsh GI, Satchell SC, Ye Y, Mathieson PW, Bates DO, Saleem MA (2009) Flufenamic acid is a tool for investigating TRPC6-mediated calcium signalling in human conditionally immortalised podocytes and HEK293 cells. Cell Calcium 45:384-390. https://doi.org/10.1016/j.ceca.2009.01.003

Fuchs B, Rupp M, Ghofrani HA, Schermuly RT, Seeger W, Grimminger F, Gudermann T, Dietrich A, Weissmann N (2011) Diacylglycerol regulates acute hypoxic pulmonary 
vasoconstriction via TRPC6. Respir Res 12:20. https://doi.org/ 10.1186/1465-9921-12-20

Ge P, Wei L, Zhang M, Hu B, Wang K, Li Y, Liu S, Wang J, Li Y (2018) TRPC1/3/6 inhibition attenuates the TGF- $\beta 1$-induced epithelial-mesenchymal transition in gastric cancer via the Ras/ Raf1/ERK signaling pathway. Cell Biol Int 42:975-984. https:// doi.org/10.1002/cbin.10963

Ge J, Wang Y, Yan Q, Wu C, Yu H, Yang H, Zou J (2020) FK506 Induces the TGF-beta $1 / \mathrm{Smad} 3$ pathway independently of calcineurin inhibition to prevent intervertebral disk degeneration. Front Cell Dev Biol. https://doi.org/10.3389/fcell.2020.608308

Glasnov TN, Groschner K, Kappe CO (2009) High-speed microwaveassisted synthesis of the trifluoromethylpyrazol-derived canonical transient receptor potential (TRPC) channel inhibitor Pyr3. ChemMedChem 4:1816-1818. https://doi.org/10.1002/cmdc. 200900304

Gong L, Jin H, Li Y, Quan Y, Yang J, Tang Q, Zou Z (2020) Rosiglitazone ameliorates skeletal muscle insulin resistance by decreasing free fatty acids release from adipocytes. Biochem Biophy Res Commun 533:1122-1128. https://doi.org/10.1016/j.bbrc.2020. 09.144

Gong Y, Li D, Li L, Yang J, Ding H, Zhang C, Wen G, Wu C, Fang Z, Hou S, Yang Y (2021) Smad3 C-terminal phosphorylation site mutation attenuates the hepatoprotective effect of salvianolic acid B against hepatocarcinogenesis. Food Chem Toxicol 147:111912. https://doi.org/10.1016/j.fct.2020.111912

Grant P, Song JY, Swedo SE (2010) Review of the use of the glutamate antagonist riluzole in psychiatric disorders and a description of recent use in childhood obsessive-compulsive disorder. J Child Adolesc Psychopharmacol 20:309-315. https://doi.org/10.1089/ cap.2010.0009

Grant CV, Carver CM, Hastings SD, Ramachandran K, Muniswamy M, Risinger AL, Beutler JA, Mooberry SL (2019) Triple-negative breast cancer cell line sensitivity to englerin A identifies a new, targetable subtype. Breast Cancer Res Treat 177:345-355. https://doi.org/10.1007/s10549-019-05324-7

Griffin CS, Thornbury KD, Hollywood MA, Sergeant GP (2018) Muscarinic receptor-induced contractions of the detrusor are impaired in TRPC4 deficient mice. Sci Rep 8:9264. https://doi. org/10.1038/s41598-018-27617-5

Guan Y, Nakano D, Zhang Y, Li L, Liu W, Nishida M, Kuwabara T, Morishita A, Hitomi H, Mori K, Mukoyama M, Masaki T, Hirano K, Nishiyama A (2017) A protease-activated receptor-1 antagonist protects against podocyte injury in a mouse model of nephropathy. J Pharmacol Sci. https://doi.org/10.1016/j.jphs. 2017.09.002

Guan X, Li Z, Zhu S, Cheng M, Ju Y, Ren L, Yang G, Min D (2021) Galangin attenuated cerebral ischemia-reperfusion injury by inhibition of ferroptosis through activating the SLC7A11/GPX4 axis in gerbils. Life Sci 264:118660. https://doi.org/10.1016/j. lfs. 2020.118660

Haque I, Subramanian A, Huang CH, Godwin AK, Van Veldhuizen PJ, Banerjee S, Banerjee SK (2017) The role of compounds derived from natural supplement as anticancer agents in renal cell carcinoma: a review. Int J Mol Sci. https://doi.org/10.3390/ijms1 9010107

He X, Li S, Liu B, Susperreguy S, Formoso K, Yao J, Kang J, Shi A, Birnbaumer L, Liao Y (2017) Major contribution of the 3/6/7 class of TRPC channels to myocardial ischemia/reperfusion and cellular hypoxia/reoxygenation injuries. Proc Natl Acad Sci USA 114:E4582-E4591. https://doi.org/10.1073/pnas.1621384114

He C, Gao P, Cui Y, Li Q, Li Y, Lu Z, Ma H, Zhao Y, Li L, Sun F, Chen X, Jia H, Liu D, Yang G, Zheng H, Zhu Z (2020) Low-glucosesensitive TRPC6 dysfunction drives hypoglycemia-induced cognitive impairment in diabetes. Clin Transl Med 10:e205. https:// doi.org/10.1002/ctm2.205
Hofmann T, Obukhov AG, Schaefer M, Harteneck C, Gudermann T, Schultz G (1999) Direct activation of human TRPC6 and TRPC3 channels by diacylglycerol. Nature 397:259-263. https://doi.org/10.1038/16711

Hofmann L, Wang H, Zheng W, Philipp SE, Hidalgo P, Cavalié A, Chen XZ, Beck A, Flockerzi V (2017) The S4-S5 linker-gearbox of TRP channel gating. Cell Calcium 67:156-165. https:// doi.org/10.1016/j.ceca.2017.04.002

Hong C, Seo H, Kwak M, Jeon J, Jang J, Jeong EM, Myeong J, Hwang YJ, Ha K, Kang MJ, Lee KP, Yi EC, Kim IG, Jeon JH, Ryu H, So I (2015) Increased TRPC5 glutathionylation contributes to striatal neuron loss in Huntington's disease. Brain 138:3030-3047. https://doi.org/10.1093/brain/awv188

Hou X, Xiao HT, Zhang YH, Zeng XX, Huang MJ, Chen XY, Birnbaumer L, Liao YH (2018) Transient receptor potential channel 6 knockdown prevents apoptosis of renal tubular epithelial cells upon oxidative stress via autophagy activation. Cell Death Dis 9:15. https://doi.org/10.1038/s41419-018-1052-5

Hsu FT, Chen WT, Wu CT, Chung JG (2020) Hyperforin induces apoptosis through extrinsic/intrinsic pathways and inhibits EGFR/ERK/NF- $\mathrm{kB}$-mediated anti-apoptotic potential in glioblastoma. Environ Toxicol 35:1058-1069. https://doi.org/10. 1002/tox.22942

Hu L, Chen H, Zhang X, Feng Z, Zhang H, Meng Q (2020a) Rosiglitazone ameliorates radiation-induced intestinal inflammation in rats by inhibiting NLRP3 inflammasome and TNF-alpha production. J Radiat Res 61:842-850. https://doi.org/10.1093/ jrr/rraa062

Hu Y, Wang M, Pan Y, Li Q, Xu L (2020b) Salvianolic acid B attenuates renal interstitial fibrosis by regulating the HPSE/SDC1 axis. Mol Med Rep 22:1325-1334. https://doi.org/10.3892/ mmr.2020.11229

Hu Y, Wang X, Li Q, Pan Y, Xu L (2020c) Salvianolic acid B alleviates myocardial ischemic injury by promoting mitophagy and inhibiting activation of the NLRP3 inflammasome. Mol Med Rep 22:5199-5208. https://doi.org/10.3892/mmr.2020.11589

Hu Y, Xia W, Li Y, Wang Q, Lin S, Wang B, Zhou C, Cui Y, Jiang Y, Pu X, Wei X, Wu H, Zhang H, Zhu Z, Liu D, Li Z (2020d) High-salt intake increases TRPC 3 expression and enhances TRPC3-mediated calcium influx and systolic blood pressure in hypertensive patients. Hypertens Res 43:679-687. https:// doi.org/10.1038/s41440-020-0409-1

Huai M, Zeng J, Ge W (2020) Artemisinin ameliorates intestinal inflammation by skewing macrophages to the M2 phenotype and inhibiting epithelial-mesenchymal transition. Int Immunopharmacol 91:107284. https://doi.org/10.1016/j.intimp. 2020.107284

Huang W, Cheng P, Yu K, Han Y, Song M, Li Y (2017) Hyperforin attenuates aluminum-induced $\mathrm{A} \beta$ production and Tau phosphorylation via regulating Akt/GSK-3 $\beta$ signaling pathway in PC12 cells. Biomed Pharmacother 96:1-6. https://doi.org/10.1016/j. biopha.2017.09.114

Huang H, Chen AY, Ye X, Guan R, Rankin GO, Chen YC (2020) Galangin, a flavonoid from lesser galangal, induced apoptosis via p53-dependent pathway in ovarian cancer cells. Molecules. https://doi.org/10.3390/molecules25071579

Hwang JA, Hwang MK, Jang Y, Lee EJ, Kim JE, Oh MH, Shin DJ, Lim S, Ji G, Oh U, Bode AM, Dong Z, Lee KW, Lee HJ (2013) 20 -O- $\beta$-d-glucopyranosyl-20(S)-protopanaxadiol, a metabolite of ginseng, inhibits colon cancer growth by targeting TRPC channel-mediated calcium influx. J Nutr Biochem 24:1096-1104. https://doi.org/10.1016/j.jnutbio.2012.08.008

Ilatovskaya DV, Levchenko V, Lowing A, Shuyskiy LS, Palygin O, Staruschenko A (2015) Podocyte injury in diabetic nephropathy: implications of angiotensin II-dependent activation of TRPC channels. Sci Rep 5:17637. https://doi.org/10.1038/srep17637 
Jardin I, Diez-Bello R, Lopez JJ, Redondo PC, Salido GM, Smani T, Rosado JA (2018) TRPC6 channels are required for proliferation, migration and invasion of breast cancer cell lines by modulation of orai1 and orai3 surface exposure. Cancers (Basel). https://doi.org/10.3390/cancers10090331

Jasper C, Wittenberg R, Quitschalle M, Jakupovic J, Kirschning A (2005) Total synthesis and elucidation of the absolute configuration of the diterpene tonantzitlolone. Org Lett 7:479-482. https://doi.org/10.1021/o1047559e

Jeon JP, Hong C, Park EJ, Jeon JH, Cho NH, Kim IG, Choe H, Muallem S, Kim HJ, So I (2012) Selective Galphai subunits as novel direct activators of transient receptor potential canonical (TRPC)4 and TRPC5 channels. J Biol Chem 287:1702917039. https://doi.org/10.1074/jbc.M111.326553

Jiang HN, Zeng B, Zhang Y, Daskoulidou N, Fan H, Qu JM, Xu SZ (2013) Involvement of TRPC channels in lung cancer cell differentiation and the correlation analysis in human non-small cell lung cancer. PLoS ONE 8:e67637. https://doi.org/10.1371/ journal.pone. 0067637

Jiang X, Kumar M, Zhu Y (2018) Protective effect of hyperforin on $\beta$ amyloid protein induced apoptosis in PC12 cells and colchicine induced Alzheimer's disease: an anti-oxidant and antiinflammatory therapy. J Oleo Sci 67:1443-1453. https://doi. org/10.5650/jos.ess 18117

Jiang L, Wang J, Ju J, Dai J (2020a) Salvianolic acid B and sodium tanshinone II A sulfonate prevent pulmonary fibrosis through anti-inflammatory and anti-fibrotic process. Eur J Pharmacol 883:173352. https://doi.org/10.1016/j.ejphar.2020.173352

Jiang YY, Shui JC, Zhang BX, Chin JW, Yue RS (2020b) The potential roles of artemisinin and its derivatives in the treatment of type 2 diabetes mellitus. Front Pharmacol 11:585487. https:// doi.org/10.3389/fphar.2020.585487

Just S, Chenard BL, Ceci A, Strassmaier T, Chong JA, Blair NT, Gallaschun RJ, Del Camino D, Cantin S, D'Amours M, Eickmeier C, Fanger CM, Hecker C, Hessler DP, Hengerer B, Kroker KS, Malekiani S, Mihalek R, McLaughlin J, Rast G, Witek J, Sauer A, Pryce CR, Moran MM (2018) Treatment with HC-070, a potent inhibitor of TRPC4 and TRPC5, leads to anxiolytic and antidepressant effects in mice. PLoS ONE 13:e0191225. https://doi.org/10.1371/journal.pone.0191225

Kalhotra P, Chittepu V (2019) Discovery of galangin as a potential DPP-4 inhibitor that improves insulin-stimulated skeletal muscle glucose uptake: a combinational therapy for diabetes. Int $\mathbf{J}$ Mol Sci. https://doi.org/10.3390/ijms20051228

Kayalar E, Deynek GT, Tok OE, Kucuk S (2020) Effect of salvianolic acid $\mathrm{B}$ on new bone formation in the orthopedically expanded suture. Angle Orthod. https://doi.org/10.2319/042620-360.1

Kim JH, Hwang KH, Eom M, Kim M, Park EY, Jeong Y, Park KS, Cha SK (2019) WNK1 promotes renal tumor progression by activating TRPC6-NFAT pathway. FASEB J 33:8588-8599. https://doi.org/10.1096/fj.201802019RR

Kino T, Hatanaka H, Miyata S, Inamura N, Nishiyama M, Yajima T, Goto T, Okuhara M, Kohsaka M, Aoki H, Ochiai T (1987) FK-506, a novel immunosuppressant isolated from a Streptomyces. II. Immunosuppressive effect of FK-506 in vitro. J Antibiot (Tokyo) 40:1256-1265. https://doi.org/10.7164/antib iotics. 40.1256

Kitajima N, Numaga-Tomita T, Watanabe M, Kuroda T, Nishimura A, Miyano K, Yasuda S, Kuwahara K, Sato Y, Ide T, Birnbaumer L, Sumimoto H, Mori Y, Nishida M (2016) TRPC3 positively regulates reactive oxygen species driving maladaptive cardiac remodeling. Sci Rep 6:37001. https://doi.org/10. 1038/srep37001

Klein S, Mentrup B, Timmen M, Sherwood J, Lindemann O, Fobker M, Kronenberg D, Pap T, Raschke MJ, Stange R (2020) Modulation of transient receptor potential channels 3 and 6 regulates osteoclast function with impact on trabecular bone loss. Calcif Tissue Int 106:655-664. https://doi.org/10.1007/ s00223-020-00673-8

Kong Y, Feng Z, Chen A, Qi Q, Han M, Wang S, Zhang Y, Zhang X, Yang N, Wang J, Huang B, Zhang Q, Xiang G, Li W, Zhang D, Wang J, Li X (2019) The natural flavonoid galangin elicits apoptosis, pyroptosis, and autophagy in glioblastoma. Front Oncol 9:942. https://doi.org/10.3389/fonc.2019.00942

Kraft R (2007) The $\mathrm{Na}^{+} / \mathrm{Ca}^{2+}$ exchange inhibitor KB-R7943 potently blocks TRPC channels. Biochem Biophys Res Commun 361:230-236. https://doi.org/10.1016/j.bbrc.2007.07.019

Krout D, Schaar A, Sun Y, Sukumaran P, Roemmich JN, Singh BB, Claycombe-Larson KJ (2017) The TRPC1 $\mathrm{Ca}^{2+}$-permeable channel inhibits exercise-induced protection against high-fat dietinduced obesity and type II diabetes. J Biol Chem 292:2079920807. https://doi.org/10.1074/jbc.M117.809954

Laakmann G, Schule C, Baghai T, Kieser M (1998) St. John's wort in mild to moderate depression: the relevance of hyperforin for the clinical efficacy. Pharmacopsychiatry 31(Suppl 1):54-59. https:// doi.org/10.1055/s-2007-979346

Lee JH, Wu WH, Huang XY, Jun JY, Choi S (2020a) Transient receptor potential canonical 4 and 5 channel antagonist ML204 depolarized pacemaker potentials of interstitial cells of cajal. J Neurogastroenterol Motil 26:521-528. https://doi.org/10.5056/jnm20 064

Lee SH, Tonello R, Choi Y, Jung SJ, Berta T (2020b) Sensory neuronexpressed TRPC4 Is a target for the relief of psoriasiform itch and skin inflammation in mice. J Invest Dermatol 140:2221-9. e6. https://doi.org/10.1016/j.jid.2020.03.959

Leuner K, Heiser JH, Derksen S, Mladenov MI, Fehske CJ, Schubert R, Gollasch M, Schneider G, Harteneck C, Chatterjee SS, Muller WE (2010) Simple 2,4-diacylphloroglucinols as classic transient receptor potential- 6 activators-identification of a novel pharmacophore. Mol Pharmacol 77:368-377. https://doi.org/10.1124/ mol.109.057513

Li H (2017) TRP channel classification. Adv Exp Med Biol 976:1-8. https://doi.org/10.1007/978-94-024-1088-4_1

Li J, Zhang X, Song X, Liu R, Zhang J, Li Z (2019a) The structure of TRPC ion channels. Cell Calcium 80:25-28. https://doi.org/10. 1016/j.ceca.2019.03.005

Li N, He Y, Yang G, Yu Q, Li M (2019b) Role of TRPC1 channels in pressure-mediated activation of airway remodeling. Respir Res 20:91. https://doi.org/10.1186/s12931-019-1050-x

Li CL, Liu B, Wang ZY, Xie F, Qiao W, Cheng J, Kuang JY, Wang Y, Zhang MX, Liu DS (2020a) Salvianolic acid B improves myocardial function in diabetic cardiomyopathy by suppressing IGFBP3. J Mol Cell Cardiol 139:98-112. https://doi.org/10. 1016/j.yjmcc.2020.01.009

Li L, Li R, Zhu R, Chen B, Tian Y, Zhang H, Xia B, Jia Q, Wang L, Zhao D, Mo F, Li Y, Zhang S (2020b) Salvianolic acid B prevents body weight gain and regulates gut microbiota and LPS/ TLR4 signaling pathway in high-fat diet-induced obese mice. Food Funct 11:8743-8756. https://doi.org/10.1039/d0fo01116a

Liang C, Zhang Y, Zhuo D, Lo CY, Yu L, Lau CW, Kwan YW, Tse G, Huang Y, Yao X (2019) Endothelial cell transient receptor potential channel C5 (TRPC5) is essential for endothelium-dependent contraction in mouse carotid arteries. Biochem Pharmacol 159:11-24. https://doi.org/10.1016/j.bcp.2018.11.002

Liao D, Chen Y, Guo Y, Wang C, Liu N, Gong Q, Fu Y, Fu Y, Cao L, Yao D, Jiang P (2020) Salvianolic acid B improves chronic mild stress-induced depressive behaviors in rats: involvement of AMPK/SIRT1 signaling pathway. J Inflamm Res 13:195-206. https://doi.org/10.2147/jir.s249363

Lin Y, Zhang JC, Fu J, Chen F, Wang J, Wu ZL, Yuan SY (2013) Hyperforin attenuates brain damage induced by transient middle cerebral artery occlusion (MCAO) in rats via inhibition 
of TRPC6 channels degradation. J Cereb Blood Flow Metab 33:253-262. https://doi.org/10.1038/jcbfm.2012.164

Lin BL, Matera D, Doerner JF, Zheng N, Del Camino D, Mishra S, Bian H, Zeveleva S, Zhen X, Blair NT, Chong JA, Hessler DP, Bedja D, Zhu G, Muller GK, Ranek MJ, Pantages L, McFarland M, Netherton MR, Berry A, Wong D, Rast G, Qian HS, Weldon SM, Kuo JJ, Sauer A, Sarko C, Moran MM, Kass DA, Pullen SS (2019) In vivo selective inhibition of TRPC6 by antagonist BI 749327 ameliorates fibrosis and dysfunction in cardiac and renal disease. Proc Natl Acad Sci USA 116:10156-10161. https://doi. org/10.1073/pnas.1815354116

Liu B, Wang H, Du Z, Li G, Ye H (2011) Metabolic engineering of artemisinin biosynthesis in Artemisia аппиа L. Plant Cell Rep 30:689-694. https://doi.org/10.1007/s00299-010-0967-9

Liu YC, Lin KH, Hsieh JH, Chung JG, Tan ZL, Hsu FT, Chiang CH (2019) Hyperforin induces apoptosis through extrinsic/intrinsic pathways and inhibits NF-KB-modulated survival and invasion potential in bladder cancer. In Vivo 33:1865-1877. https://doi. org/10.21873/invivo.11680

Liu J, Wang Y, Guo J, Sun J, Sun Q (2020) Salvianolic acid B improves cognitive impairment by inhibiting neuroinflammation and decreasing $\mathrm{A} \beta$ level in Porphyromonas gingivalis-infected mice. Aging (Albany NY) 12:10117-10128. https://doi.org/10.18632/ aging.103306

Lopez JR, Kaura V, Hopkins P, Liu X, Uryach A, Adams J, Allen PD (2020a) Transient receptor potential cation channels and calcium dyshomeostasis in a mouse model relevant to malignant hyperthermia. Anesthesiology 133:364-376. https://doi.org/10.1097/ aln.0000000000003387

Lopez JR, Uryash A, Adams J, Hopkins PM, Allen PD (2020b) Molecular modification of transient receptor potential canonical 6 channels modulates calcium dyshomeostasis in a mouse model relevant to malignant hyperthermia. Anesthesiology. https://doi. org/10.1097/aln.0000000000003635

Lu W, Ran P, Zhang D, Peng G, Li B, Zhong N, Wang J (2010) Sildenafil inhibits chronically hypoxic upregulation of canonical transient receptor potential expression in rat pulmonary arterial smooth muscle. Am J Physiol Cell Physiol 298:C114-C123. https://doi.org/10.1152/ajpcell.00629.2008

Ma R, Chaudhari S, Li W (2016) Canonical transient receptor potential 6 channel: a new target of reactive oxygen species in renal physiology and pathology. Antioxid Redox Signal 25:732-748. https://doi.org/10.1089/ars.2016.6661

Ma X, Tang M, Lu L, Zheng J, Huang J, Li J, Luo W (2020) Effects of salvianolic acid B on liver fibrosis: a protocol for systematic review and meta analysis. Medicine (Baltimore) 99:e21036. https://doi.org/10.1097/md.0000000000021036

Maier T, Follmann M, Hessler G, Kleemann HW, Hachtel S, Fuchs B, Weissmann N, Linz W, Schmidt T, Lohn M, Schroeter K, Wang L, Rutten H, Strubing C (2015) Discovery and pharmacological characterization of a novel potent inhibitor of diacylglycerolsensitive TRPC cation channels. Br J Pharmacol 172:3650-3660. https://doi.org/10.1111/bph.13151

Majeed Y, Bahnasi Y, Seymour VA, Wilson LA, Milligan CJ, Agarwal AK, Sukumar P, Naylor J, Beech DJ (2011) Rapid and contrasting effects of rosiglitazone on transient receptor potential TRPM3 and TRPC5 channels. Mol Pharmacol 79:1023-1030. https://doi.org/10.1124/mol.110.069922

Merritt JE, Armstrong WP, Benham CD, Hallam TJ, Jacob R, JaxaChamiec A, Leigh BK, McCarthy SA, Moores KE, Rink TJ (1990) SK\&F 96365, a novel inhibitor of receptor-mediated calcium entry. Biochem J 271:515-522. https://doi.org/10.1042/ bj2710515

Mignani S, Shi X, Zablocka M, Majoral JP (2019) Dendrimer-enabled therapeutic antisense delivery systems as innovation in medicine.
Bioconjugate Chem 30:1938-1950. https://doi.org/10.1021/acs. bioconjchem.9b00385

Millares-Ramirez EM, Picotte K, Lavoie JP (2021) Pulmonary response of severely asthmatic horses after intra-articular administration of methylprednisolone. Equine Vet J 53:78-84. https://doi.org/ 10.1111/evj.13272

Miller RG, Mitchell JD, Moore DH (2000) Riluzole for amyotrophic lateral sclerosis (ALS)/motor neuron disease (MND). Cochrane Database Syst Rev. https://doi.org/10.1002/14651858.Cd001447

Minard A, Bauer CC, Wright DJ, Rubaiy HN, Muraki K, Beech DJ, Bon RS (2018) Remarkable progress with small-molecule modulation of TRPC $1 / 4 / 5$ channels: implications for understanding the channels in health and disease. Cells. https://doi.org/10.3390/ cells 7060052

Miller M, Shi J, Zhu Y, Kustov M, Tian JB, Stevens A, Wu M, Xu J, Long S, Yang P, Zholos AV, Salovich JM, Weaver CD, Hopkins CR, Lindsley CW, McManus O, Li M, Zhu MX (2011) Identification of ML204, a novel potent antagonist that selectively modulates native TRPC4/C5 ion channels. J Biol Chem 286:33436-33446. https://doi.org/10.1074/jbc.M111.274167

Minard A, Bauer CC, Chuntharpursat-Bon E, Pickles IB, Wright DJ, Ludlow MJ, Burnham MP, Warriner SL, Beech DJ, Muraki K, Bon RS (2019) Potent, selective, and subunit-dependent activation of TRPC5 channels by a xanthine derivative. Br J Pharmacol 176:3924-3938. https://doi.org/10.1111/bph.14791

Minke B, Cook B (2002) TRP channel proteins and signal transduction. Physiol Rev 82:429-472. https://doi.org/10.1152/physrev. 00001.2002

Minke B, Wu C, Pak WL (1975) Induction of photoreceptor voltage noise in the dark in Drosophila mutant. Nature 258:84-87. https://doi.org/10.1038/258084a0

Moiseenkova-Bell V, Wensel TG (2011) Functional and structural studies of TRP channels heterologously expressed in budding yeast. Adv Exp Med Biol 704:25-40. https://doi.org/10.1007/ 978-94-007-0265-3_2

Motoyama K, Nagata T, Kobayashi J, Nakamura A, Miyoshi N, Kazui M, Sakurai K, Sakakura T (2018) Discovery of a bicyclo[4.3.0] nonane derivative DS88790512 as a potent, selective, and orally bioavailable blocker of transient receptor potential canonical 6 (TRPC6). Bioorg Med Chem Lett 28:2222-2227. https://doi.org/ 10.1016/j.bmcl.2018.03.056

Munakata M, Shirakawa H, Nagayasu K, Miyanohara J, Miyake T, Nakagawa T, Katsuki H, Kaneko S (2013) Transient receptor potential canonical 3 inhibitor Pyr3 improves outcomes and attenuates astrogliosis after intracerebral hemorrhage in mice. Stroke 44:1981-1987. https://doi.org/10.1161/strokeaha.113. 679332

Muraki K, Ohnishi K, Takezawa A, Suzuki H, Hatano N, Muraki Y, Hamzah N, Foster R, Waldmann H, Nussbaumer P (2017) $\mathrm{Na}(+)$ entry through heteromeric TRPC4/C1 channels mediates (-)englerin A-induced cytotoxicity in synovial sarcoma cells. Sci Rep 7:16988. https://doi.org/10.1038/s41598-017-17303-3

Nagamine K, Kudoh J, Minoshima S, Kawasaki K, Asakawa S, Ito F, Shimizu N (1998) Molecular cloning of a novel putative Ca2+ channel protein (TRPC7) highly expressed in brain. Genomics 54:124-131. https://doi.org/10.1006/geno.1998.5551

Naylor J, Minard A, Gaunt HJ, Amer MS, Wilson LA, Migliore M, Cheung SY, Rubaiy HN, Blythe NM, Musialowski KE, Ludlow MJ, Evans WD, Green BL, Yang H, You Y, Li J, Fishwick CW, Muraki K, Beech DJ, Bon RS (2016) Natural and synthetic flavonoid modulation of TRPC5 channels. Br J Pharmacol 173:562574. https://doi.org/10.1111/bph.13387

Okada T, Shimizu S, Wakamori M, Maeda A, Kurosaki T, Takada N, Imoto K, Mori Y (1998) Molecular cloning and functional characterization of a novel receptor-activated TRP $\mathrm{Ca}^{2+}$ 
channel from mouse brain. J Biol Chem 273:10279-10287. https://doi.org/10.1074/jbc.273.17.10279

Orth HC, Rentel C, Schmidt PC (1999) Isolation, purity analysis and stability of hyperforin as a standard material from Hypericum perforatum L. J Pharm Pharmacol 51:193-200. https://doi.org/ $10.1211 / 0022357991772132$

Pablo JL, Greka A (2019) Charting a TRP to novel therapeutic destinations for kidney diseases. Trends Pharmacol Sci 40:911-918. https://doi.org/10.1016/j.tips.2019.10.001

Park SE, Song JH, Hong C, Kim DE, Sul JW, Kim TY, Seo BR, So I, Kim SY, Bae DJ, Park MH, Lim HM, Baek IJ, Riccio A, Lee JY, Shim WH, Park B, Koh JY, Hwang JJ (2019) Contribution of zinc-dependent delayed calcium influx via TRPC5 in oxidative neuronal death and its prevention by novel TRPC antagonist. Mol Neurobiol 56:2822-2835. https://doi.org/10. 1007/s12035-018-1258-7

Park MK, Choi BY, Kho AR, Lee SH, Hong DK, Jeong JH, Kang DH, Kang BS, Suh SW (2020) Effects of transient receptor potential cation 5 (TRPC5) inhibitor, NU6027, on hippocampal neuronal death after traumatic brain injury. Int J Mol Sci. https://doi.org/10.3390/ijms21218256

Pfeffer TJ, Sasse F, Schmidt CF, Lakamper S, Kirschning A, Scholz $\mathrm{T}$ (2016) The natural diterpene tonantzitlolone $\mathrm{A}$ and its synthetic enantiomer inhibit cell proliferation and kinesin-5 function. Eur J Med Chem 112:164-170. https://doi.org/10.1016/j. ejmech.2016.02.022

Pochwat B, Szewczyk B, Kotarska K, Rafało-Ulińska A, Siwiec M, Sowa JE, Tokarski K, Siwek A, Bouron A, Friedland K, Nowak G (2018) Hyperforin potentiates antidepressant-like activity of lanicemine in mice. Front Mol Neurosci 11:456. https://doi. org/10.3389/fnmol.2018.00456

Polat OK, Uno M, Maruyama T, Tran HN, Imamura K, Wong CF, Sakaguchi R, Ariyoshi M, Itsuki K, Ichikawa J, Morii T, Shirakawa $\mathrm{M}$, Inoue $\mathrm{R}$, Asanuma $\mathrm{K}$, Reiser J, Tochio H, Mori Y, Mori MX (2019) Contribution of coiled-coil assembly to $\mathrm{Ca}^{2+}$ / calmodulin-dependent inactivation of TRPC6 channel and its impacts on FSGS-associated phenotypes. J Am Soc Nephrol 30:1587-1603. https://doi.org/10.1681/asn.2018070756

Qu C, Ding M, Zhu Y, Lu Y, Du J, Miller M, Tian J, Zhu J, Xu J, Wen M, Er-Bu A, Wang J, Xiao Y, Wu M, McManus OB, Li M, Wu J, Luo HR, Cao Z, Shen B, Wang H, Zhu MX, Hong $X$ (2017) Pyrazolopyrimidines as potent stimulators for transient receptor potential canonical 3/6/7 channels. J Med Chem 60:4680-4692. https://doi.org/10.1021/acs.jmedchem.7b00304

Ramanathan G, Mannhalter C (2016) Increased expression of transient receptor potential canonical 6 (TRPC6) in differentiating human megakaryocytes. Cell Biol Int 40:223-231. https://doi. org/10.1002/cbin.10558

Ratnayake R, Covell D, Ransom TT, Gustafson KR, Beutler JA (2009) Englerin A, a selective inhibitor of renal cancer cell growth, from Phyllanthus engleri. Org Lett 11:57-60. https:// doi.org/10.1021/ol802339w

Riccio A, Li Y, Tsvetkov E, Gapon S, Yao GL, Smith KS, Engin E, Rudolph U, Bolshakov VY, Clapham DE (2014) Decreased anxiety-like behavior and Goq/11-dependent responses in the amygdala of mice lacking TRPC4 channels. J Neurosci 34:3653-3667. https://doi.org/10.1523/jneurosci.2274-13.2014

Richter JM, Schaefer M, Hill K (2014a) Clemizole hydrochloride is a novel and potent inhibitor of transient receptor potential channel TRPC5. Mol Pharmacol 86:514-521. https://doi.org/ 10.1124/mol.114.093229

Richter JM, Schaefer M, Hill K (2014b) Riluzole activates TRPC5 channels independently of PLC activity. Br J Pharmacol 171:158-170. https://doi.org/10.1111/bph.12436
Rubaiy HN (2019) Treasure troves of pharmacological tools to study transient receptor potential canonical $1 / 4 / 5$ channels. $\mathrm{Br}$ J Pharmacol 176:832-846. https://doi.org/10.1111/bph.14578

Rubaiy HN, Ludlow MJ, Bon RS, Beech DJ (2017a) Pico145-powerful new tool for TRPC1/4/5 channels. Channels 11:362-364. https://doi.org/10.1080/19336950.2017.1317485

Rubaiy HN, Ludlow MJ, Henrot M, Gaunt HJ, Miteva K, Cheung SY, Tanahashi Y, Hamzah N, Musialowski KE, Blythe NM, Appleby HL, Bailey MA, McKeown L, Taylor R, Foster R, Waldmann H, Nussbaumer P, Christmann M, Bon RS, Muraki K, Beech DJ (2017b) Picomolar, selective, and subtype-specific small-molecule inhibition of TRPC1/4/5 channels. J Biol Chem 292:8158-8173. https://doi.org/10.1074/jbc.M116. 773556

Rubaiy HN, Ludlow MJ, Siems K, Norman K, Foster R, Wolf D, Beutler JA, Beech DJ (2018) Tonantzitlolone is a nanomolar potency activator of transient receptor potential canonical 1/4/5 channels. Br J Pharmacol 175:3361-3368. https://doi.org/10. 1111/bph.14379

Sangaraju R, Nalban N, Alavala S, Rajendran V, Jerald MK, Sistla $R$ (2019) Protective effect of galangin against dextran sulfate sodium (DSS)-induced ulcerative colitis in Balb/c mice. Inflamm Res 68:691-704. https://doi.org/10.1007/s00011-019-01252-w

Santiago-Vacas E, García-Lunar I, Solanes N, Dantas AP, Ascaso M, Jimenez-Trinidad FR, Ramirez J, Fernández-Friera L, Galán C, Sánchez J, Sabaté M, Pérez-Villa F, Rigol M, Pereda D, Ibañez B, García-Álvarez A (2021) Effect of sildenafil on right ventricular performance in an experimental large-animal model of postcapillary pulmonary hypertension. Transl Res 228:64-75. https://doi. org/10.1016/j.trsl.2020.08.006

Sato A, Arichi S, Kojima F, Hayashi T, Ohba T, Cheung DL, Eto K, Narushima M, Murakoshi H, Maruo Y, Kadoya Y, Nabekura J, Ishibashi H (2020) Histamine depolarizes rat intracardiac ganglion neurons through the activation of TRPC non-selective cation channels. Eur J Pharmacol 886:173536. https://doi.org/10. 1016/j.ejphar.2020.173536

Schempp CM, Kirkin V, Simon-Haarhaus B, Kersten A, Kiss J, Termeer CC, Gilb B, Kaufmann T, Borner C, Sleeman JP, Simon JC (2002) Inhibition of tumour cell growth by hyperforin, a novel anticancer drug from St. John's wort that acts by induction of apoptosis. Oncogene 21:1242-1250. https://doi.org/10.1038/sj. onc. 1205190

Sekaran S, Lall GS, Ralphs KL, Wolstenholme AJ, Lucas RJ, Foster RG, Hankins MW (2007) 2-Aminoethoxydiphenylborane is an acute inhibitor of directly photosensitive retinal ganglion cell activity in vitro and in vivo. J Neurosci 27:3981-3986. https:// doi.org/10.1523/jneurosci.4716-06.2007

Šemeláková M, Sačková V, Fedoročko P (2018) The potential of hypericin and hyperforin for antiadhesion therapy to prevent metastasis of parental and oxaliplatin-resistant human adenocarcinoma cells (HT-29). Anticancer Drugs 29:983-994. https:// doi.org/10.1097/cad.0000000000000676

Sevastre-Berghian AC, Toma VA, Sevastre B, Hanganu D, Vlase L, Benedec D, Oniga I, Baldea I, Olteanu D, Moldovan R, Decea N, Filip GA, Clichici SV (2018) Characterization and biological effects of Hypericum extracts on experimentally-induced - anxiety, oxidative stress and inflammation in rats. J Physiol Pharmacol. https://doi.org/10.26402/jpp.2018.5.13

Sharma SH, Pablo JL, Montesinos MS, Greka A, Hopkins CR (2019) Design, synthesis and characterization of novel N-heterocyclic1-benzyl-1H-benzo[d]imidazole-2-amines as selective TRPC5 inhibitors leading to the identification of the selective compound, AC1903. Bioorg Med Chem Lett 29:155-159. https://doi.org/10. 1016/j.bmcl.2018.12.007

Shen S, Liao Q, Lyu M, Wong YK, Zhang X, Zhou J, Ma N, Wang J (2020) The potential of artemisinins as anti-obesity agents via 
modulating the immune system. Pharmacol Ther 216:107696. https://doi.org/10.1016/j.pharmthera.2020.107696

Shi Y, Pan D, Yan L, Chen H, Zhang X, Yuan J, Mu B (2020) Salvianolic acid B improved insulin resistance through suppression of hepatic ER stress inob/ob mice. Biochem Biophys Res Commun 526:733-737. https://doi.org/10.1016/j.bbrc.2020.03.124

Shinjyo N, Nakayama H, Li L, Ishimaru K, Hikosaka K, Suzuki N, Yoshida H, Norose K (2021) Hypericum perforatum extract and hyperforin inhibit the growth of neurotropic parasite Toxoplasma gondii and infection-induced inflammatory responses of glial cells in vitro. J Ethnopharmacol 267:113525. https://doi.org/10. 1016/j.jep.2020.113525

Silva J, Ballejo G (2019) Pharmacological characterization of the calcium influx pathways involved in nitric oxide production by endothelial cells. Einstein 17:O4600. https://doi.org/10.31744/ einstein_journal/2019AO4600

Singer A, Wonnemann M, Muller WE (1999) Hyperforin, a major antidepressant constituent of St. John's Wort, inhibits serotonin uptake by elevating free intracellular $\mathrm{Na}^{+}$. J Pharmacol Exp Ther 290:1363-1368

Singh A, Hildebrand ME, Garcia E, Snutch TP (2010) The transient receptor potential channel antagonist SKF96365 is a potent blocker of low-voltage-activated T-type calcium channels. Br J Pharmacol 160:1464-1475. https://doi.org/10.1111/j.1476-5381. 2010.00786.x

Song M, Chen D, Yu SP (2014) The TRPC channel blocker SKF 96365 inhibits glioblastoma cell growth by enhancing reverse mode of the $\mathrm{Na}^{+} / \mathrm{Ca}^{2+}$ exchanger and increasing intracellular $\mathrm{Ca}^{2+}$. Br J Pharmacol 171:3432-3447. https://doi.org/10.1111/bph.12691

Song HY, Kim WS, Han JM, Seo HS, Lim ST, Byun EB (2021) Galangin treatment during dendritic cell differentiation confers tolerogenic properties in response to lipopolysaccharide stimulation. J Nutr Biochem 87:108524. https://doi.org/10.1016/j.jnutb io. 2020.108524

Sonneveld R, Hoenderop JG, Isidori AM, Henique C, Dijkman HB, Berden JH, Tharaux PL, van der Vlag J, Nijenhuis T (2017) Sildenafil prevents podocyte injury via PPAR-gamma-mediated TRPC6 inhibition. J Am Soc Nephrol 28:1491-1505. https://doi. org/10.1681/asn.2015080885

Sourbier C, Scroggins BT, Mannes PZ, Liao PJ, Siems K, Wolf D, Beutler JA, Linehan WM, Neckers L (2015) Tonantzitlolone cytotoxicity toward renal cancer cells is PKC $\theta$ - and HSF1dependent. Oncotarget 6:29963-29974. https://doi.org/10.18632/ oncotarget.4676

Staruschenko A, Spires D, Palygin O (2019) Role of TRPC6 in progression of diabetic kidney disease. Curr Hypertens Rep 21:48. https://doi.org/10.1007/s11906-019-0960-9

Stringham RW, Moore GL, Teager DS, Yue TY (2018) Analysis and isolation of potential artemisinin precursors from waste streams of Artemisia annua extraction. ACS Omega 3:7803-7808. https://doi.org/10.1021/acsomega.8b00974

Strzelczyk A, Schubert-Bast S (2020) Therapeutic advances in dravet syndrome: a targeted literature review. Expert Rev Neurother 20:1065-1079. https://doi.org/10.1080/14737175.2020.1801423

Su H, Ma Z, Guo A, Wu H, Yang X (2020) Salvianolic acid B protects against sepsis-induced liver injury via activation of SIRT1/ PGC-1 $\alpha$ signaling. Exp Ther Med 20:2675-2683. https://doi.org/ 10.3892/etm.2020.9020

Sukumaran P, Sun Y, Schaar A, Selvaraj S, Singh BB (2017) TRPC channels and Parkinson's disease. Adv Exp Med Biol 976:85-94. https://doi.org/10.1007/978-94-024-1088-4_8

Szewczyk B, Pochwat B, Muszyńska B, Opoka W, Krakowska A, Rafało-Ulińska A, Friedland K, Nowak G (2019) Antidepressant-like activity of hyperforin and changes in BDNF and zinc levels in mice exposed to chronic unpredictable mild stress.
Behav Brain Res 372:112045. https://doi.org/10.1016/j.bbr. 2019.112045

Tahirovic YA, Pelly S, Jecs E, Miller EJ, Sharma SK, Liotta DC, Wilson LJ (2020) Small molecule and peptide-based CXCR4 modulators as therapeutic agents. A patent review for the period from 2010 to 2018. Expert Opin Ther Pat 30:87-101. https://doi.org/ 10.1080/13543776.2020.1707186

Tai Y, Yang S, Liu Y, Shao W (2017) TRPC channels in health and disease. Adv Exp Med Biol 976:35-45. https://doi.org/10.1007/ 978-94-024-1088-4_4

Takada H, Yonekawa J, Matsumoto M, Furuya K (2017) Hyperforin/ HP- $\beta$-cyclodextrin enhances mechanosensitive $\mathrm{Ca}^{2+}$ signaling in $\mathrm{HaCaT}$ keratinocytes and in atopic skin ex vivo which accelerates wound healing. BioMed Res Int. https://doi.org/10.1155/ 2017/8701801

Tambe A, Knohl S, Gambhir HS, Tambe V (2021) Severe hyponatremia secondary to riluzole therapy in amyotropic lateral sclerosis. Am J Ther 28:e164-e165. https://doi.org/10.1097/mjt.00000 00000001023

Tang Q, Guo W, Zheng L, Wu JX, Liu M, Zhou X, Zhang X, Chen L (2018) Structure of the receptor-activated human TRPC6 and TRPC3 ion channels. Cell Res 28:746-755. https://doi.org/10. 1038/s41422-018-0038-2

Tang T, Xu T, Liu X, Yang T, Zhang L, Yang Z (2021) Roles of BATF/ JUN/IRF4 complex in tacrolimus mediated immunosuppression on Tfh cells in acute rejection after liver transplantation. J Cell Physiol 236:1776-1786. https://doi.org/10.1002/jcp.29953

Tesfai Y, Brereton HM, Barritt GJ (2001) A diacylglycerol-activated $\mathrm{Ca}^{2+}$ channel in PC12 cells (an adrenal chromaffin cell line) correlates with expression of the TRP-6 (transient receptor potential) protein. Biochem J 358:717-726. https://doi.org/10.1042/02646021:3580717

Thangaiyan R, Arjunan S, Govindasamy K, Khan HA, Alhomida AS, Prasad NR (2020) Galangin attenuates isoproterenol-induced inflammation and fibrosis in the cardiac tissue of albino wistar rats. Front Pharmacol 11:585163. https://doi.org/10.3389/fphar. 2020.585163

Thapak P, Vaidya B, Joshi HC, Singh JN, Sharma SS (2020) Therapeutic potential of pharmacological agents targeting TRP channels in CNS disorders. Pharmacol Res 159:105026. https://doi.org/ 10.1016/j.phrs.2020.105026

Tian S, Chen M, Wang B, Han Y, Shang H, Chen J (2021) Salvianolic acid B blocks hepatic stellate cell activation via FGF19/FGFR4 signaling. Ann Hepatol 20:100259. https://doi.org/10.1016/j. aohep.2020.07.013

Trinh T, Park SB, Murray J, Pickering H, Lin CSY, Martin A, Friedlander M, Kiernan MC, Goldstein D, Krishnan AV (2021) Neuhorizons: neuroprotection and therapeutic use of riluzole for the prevention of oxaliplatin-induced neuropathy-a randomised controlled trial. Support Care Cancer 29:1103-1110. https://doi. org/10.1007/s00520-020-05591-x

Tu P, Kunert-Keil C, Lucke S, Brinkmeier H, Bouron A (2009) Diacylglycerol analogues activate second messenger-operated calcium channels exhibiting TRPC-like properties in cortical neurons. J Neurochem 108:126-138. https://doi.org/10.1111/j.1471-4159. 2008.05752.x

Tu P, Gibon J, Bouron A (2010) The TRPC6 channel activator hyperforin induces the release of zinc and calcium from mitochondria. J Neurochem 112:204-213. https://doi.org/10.1111/j.1471-4159. 2009.06446.x

Urban N, Schaefer M (2020) Direct activation of TRPC3 channels by the antimalarial agent artemisinin. Cells. https://doi.org/10. 3390/cells9010202

Urban N, Wang L, Kwiek S, Rademann J, Kuebler WM, Schaefer M (2016) Identification and validation of larixyl acetate as a potent 
TRPC6 inhibitor. Mol Pharmacol 89:197-213. https://doi.org/ 10.1124/mol.115.100792

Uryash A, Flores V, Adams JA, Allen PD, Lopez JR (2020) Memory and learning deficits are associated with $\mathrm{Ca}^{2+}$ dyshomeostasis in normal aging. Front Aging Neurosci. https://doi.org/10.3389/ fnagi.2020.00224

van der Pluijm RW, Amaratunga C, Dhorda M, Dondorp AM (2021) Triple artemisinin-based combination therapies for malaria-a new paradigm? Trends Parasitol 37:15-24. https://doi.org/10. 1016/j.pt.2020.09.011

van der Wijst J, Bindels RJM (2018) Renal physiology: TRPC5 inhibition to treat progressive kidney disease. Nat Rev Nephrol 14:145-146. https://doi.org/10.1038/nrneph.2018.4

Venkatachalam K, Zheng F, Gill DL (2003) Regulation of canonical transient receptor potential (TRPC) channel function by diacylglycerol and protein kinase C. J Biol Chem 278:29031-29040. https://doi.org/10.1074/jbc.M302751200

Vinayagam D, Mager T, Apelbaum A, Bothe A, Merino F, Hofnagel O, Gatsogiannis C, Raunser S (2018) Electron cryo-microscopy structure of the canonical TRPC4 ion channel. Elife. https://doi. org/10.7554/eLife.36615

Wang J, Weigand L, Lu W, Sylvester JT, Semenza GL, Shimoda LA (2006) Hypoxia inducible factor 1 mediates hypoxia-induced TRPC expression and elevated intracellular $\mathrm{Ca}^{2+}$ in pulmonary arterial smooth muscle cells. Circ Res 98:1528-1537. https://doi. org/10.1161/01.Res.0000227551.68124.98

Wang J, Yang K, Xu L, Zhang Y, Lai N, Jiang H, Zhang Y, Zhong N, Ran P, Lu W (2013) Sildenafil inhibits hypoxia-induced transient receptor potential canonical protein expression in pulmonary arterial smooth muscle via cGMP-PKG-PPARgamma axis. Am J Respir Cell Mol Biol 49:231-240. https://doi.org/10.1165/ remb.2012-0185OC

Wang J, Lu R, Yang J, Li H, He Z, Jing N, Wang X, Wang Y (2015a) TRPC6 specifically interacts with APP to inhibit its cleavage by $\gamma$-secretase and reduce $A \beta$ production. Nat Commun 6:8876. https://doi.org/10.1038/ncomms9876

Wang T, Chen Z, Zhu Y, Pan Q, Liu Y, Qi X, Jin L, Jin J, Ma X, Hua D (2015b) Inhibition of transient receptor potential channel 5 reverses 5-fluorouracil resistance in human colorectal cancer cells. J Biol Chem 290:448-456. https://doi.org/10.1074/jbc. M114.590364

Wang T, Ning K, Sun X, Zhang C, Jin LF, Hua D (2018a) Glycolysis is essential for chemoresistance induced by transient receptor potential channel C5 in colorectal cancer. BMC Cancer 18:207. https://doi.org/10.1186/s12885-018-4123-1

Wang Y, He J, Jiang H, Zhang Q, Yang H, Xu X, Zhang C, Xu C, Wang J, Lu W (2018b) Nicotine enhances store-operated calcium entry by upregulating HIF-1 $\alpha$ and SOCC components in non-small cell lung cancer cells. Oncol Rep 40:2097-2104. https://doi.org/10. 3892/or.2018.6580

Wang H, Shao B, Yu H, Xu F, Wang P, Yu K, Han Y, Song M, Li Y, Cao Z (2019a) Neuroprotective role of hyperforin on aluminum maltolate-induced oxidative damage and apoptosis in PC12 cells and SH-SY5Y cells. Chem Biol Interact 299:15-26. https://doi. org/10.1016/j.cbi.2018.11.016

Wang HB, Huang SH, Xu M, Yang J, Yang J, Liu MX, Wan CX, Liao HH, Fan D, Tang QZ (2019b) Galangin ameliorates cardiac remodeling via the MEK1/2-ERK1/2 and PI3K-AKT pathways. J Cell Physiol 234:15654-15667. https://doi.org/10.1002/jcp. 28216

Wang L, Chang JH, Buckley AF, Spurney RF (2019c) Knockout of TRPC6 promotes insulin resistance and exacerbates glomerular injury in Akita mice. Kidney Int 95:321-332. https://doi.org/10. 1016/j.kint.2018.09.026

Wang Y, Qi YX, Qi Z, Tsang SY (2019d) TRPC3 regulates the proliferation and apoptosis resistance of triple negative breast cancer cells through the TRPC3/RASA4/MAPK pathway. Cancers (Basel). https://doi.org/10.3390/cancers11040558

Wang H, Cheng X, Tian J, Xiao Y, Tian T, Xu F, Hong X, Zhu MX (2020a) TRPC channels: structure, function, regulation and recent advances in small molecular probes. Pharmacol Ther. https://doi.org/10.1016/j.pharmthera.2020.107497

Wang J, Zhao M, Jia P, Liu FF, Chen K, Meng FY, Hong JH, Zhang T, Jin XH, Shi J (2020b) The analgesic action of larixyl acetate, a potent TRPC6 inhibitor, in rat neuropathic pain model induced by spared nerve injury. J Neuroinflammation 17:118. https://doi. org/10.1186/s12974-020-01767-8

Wang L, Liu H, He Q, Gan C, Li Y, Zhang Q, Yao Y, He F, Ye T, Yin $\mathrm{W}$ (2020c) Galangin ameliorated pulmonary fibrosis in vivo and in vitro by regulating epithelial-mesenchymal transition. Bioorg Med Chem 28:115663. https://doi.org/10.1016/j.bmc.2020. 115663

Wang Y, Liu L, Tao H, Wen L, Qin S (2020d) TRPC6 participates in the development of blood pressure variability increase in sinoaortic denervated rats. Heart Vessels 35:1755-1765. https://doi. org/10.1007/s00380-020-01682-1

Wang J, Walline JH, Yin L, Dai Y, Dai J, Zhu H, Yu X, Xu J (2021a) Efficacy of prophylactic methylprednisolone on reducing the risk of post-extubation stridor in patients after an emergency intubation: study protocol for a randomized controlled trial. Trials 22:30. https://doi.org/10.1186/s13063-020-04994-9

Wang J, Xu C, Wong YK, Ma N, Liao FL, Jiang T, Tu Y (2021b) Triple artemisinin-based combination therapies for malaria: proceed with caution. Lancet 396:1976. https://doi.org/10.1016/s01406736(20)32400-4

Watanabe H, Murakami M, Ohba T, Takahashi Y, Ito H (2008) TRP channel and cardiovascular disease. Pharmacol Ther 118:337351. https://doi.org/10.1016/j.pharmthera.2008.03.008

Wei L, Du Y, Jia L, Ma X, Chen Z, Lu J, Tian L, Duan Z, Dong F, Lv Z, Yao G, Fu R, Wang L (2017a) Therapeutic effects of FK506 on IgA nephropathy rat. Kidney Blood Press Res 42:983-998. https://doi.org/10.1159/000485346

Wei L, Mao J, Lu J, Gao J, Zhu D, Tian L, Chen Z, Jia L, Wang L, Fu $\mathrm{R}$ (2017b) Rosiglitazone inhibits angiotensin II-Induced proliferation of glomerular mesangial cells via the Goq/Plc $\beta 4 / T R P C$ signaling pathway. Cell Physiol Biochem 44:2228-2242. https:// doi.org/10.1159/000486056

Wen L, Liang C, Chen E, Chen W, Liang F, Zhi X, Wei T, Xue F, Li G, Yang Q, Gong W, Feng X, Bai X, Liang T (2016) Regulation of multi-drug resistance in hepatocellular carcinoma cells is TRPC6/calcium dependent. Sci Rep 6:23269. https://doi.org/ $10.1038 /$ srep23269

Wes PD, Chevesich J, Jeromin A, Rosenberg C, Stetten G, Montell C (1995) TRPC1, a human homolog of a Drosophila store-operated channel. Proc Natl Acad Sci USA 92:9652-9656. https://doi.org/ 10.1073/pnas.92.21.9652

Wissenbach U, Schroth G, Philipp S, Flockerzi V (1998) Structure and mRNA expression of a bovine trp homologue related to mammalian trp2 transcripts. FEBS Lett 429:61-66. https://doi.org/10. 1016/s0014-5793(98)00561-4

Woudenberg-Vrenken TE, Bindels RJ, Hoenderop JG (2009) The role of transient receptor potential channels in kidney disease. Nat Rev Nephrol 5:441-449. https://doi.org/10.1038/nrneph.2009. 100

Wright DJ, Simmons KJ, Johnson RM, Beech DJ, Muench SP, Bon RS (2020) Human TRPC5 structures reveal interaction of a xanthinebased TRPC1/4/5 inhibitor with a conserved lipid binding site. Commun Biol. https://doi.org/10.1038/s42003-020-01437-8

Wu X, Eder P, Chang B, Molkentin JD (2010) TRPC channels are necessary mediators of pathologic cardiac hypertrophy. Proc Natl Acad Sci USA 107:7000-7005. https://doi.org/10.1073/ pnas. 1001825107 
Wu YL, Xie J, An SW, Oliver N, Barrezueta NX, Lin MH, Birnbaumer L, Huang CL (2017a) Inhibition of TRPC6 channels ameliorates renal fibrosis and contributes to renal protection by soluble klotho. Kidney Int 91:830-841. https://doi.org/10.1016/j.kint. 2016.09.039

Wu Z, Zhao S, Fash DM, Li Z, Chain WJ, Beutler JA (2017b) Englerins: a comprehensive review. J Nat Prod 80:771-781. https://doi. org/10.1021/acs.jnatprod.6b01167

Wu H, Yang H, Rhee JW, Zhang JZ, Lam CK, Sallam K, Chang ACY, Ma N, Lee J, Zhang H, Blau HM, Bers DM, Wu JC (2019) Modelling diastolic dysfunction in induced pluripotent stem cellderived cardiomyocytes from hypertrophic cardiomyopathy patients. Eur Heart J 40:3685-3695. https://doi.org/10.1093/ eurheartj/ehz326

Xiao Z, Liu W, Mu YP, Zhang H, Wang XN, Zhao CQ, Chen JM, Liu $P$ (2020) Pharmacological effects of salvianolic acid B against oxidative damage. Front Pharmacol 11:572373. https://doi.org/ 10.3389/fphar.2020.572373

Xie YF, Zhou F (2014) TRPC3 channel mediates excitation of striatal cholinergic interneurons. Neurol Sci 35:1757-1761. https://doi. org/10.1007/s10072-014-1827-0

Xu SZ, Zeng F, Boulay G, Grimm C, Harteneck C, Beech DJ (2005) Block of TRPC 5 channels by 2-aminoethoxydiphenyl borate: a differential, extracellular and voltage-dependent effect. Br J Pharmacol 145:405-414. https://doi.org/10.1038/sj.bjp.0706197

Xu C, Zhang H, Mu L, Yang X (2020) Artemisinins as anticancer drugs: novel therapeutic approaches, molecular mechanisms, and clinical trials. Front Pharmacol 11:529881. https://doi.org/10. 3389/fphar.2020.529881

Yamamoto T, Wada F, Harada-Shiba M (2016) Development of antisense drugs for dyslipidemia. J Atheroscler Thromb 23:10111025. https://doi.org/10.5551/jat.RV16001

Yang SL, Cao Q, Zhou KC, Feng YJ, Wang YZ (2009) Transient receptor potential channel $\mathrm{C} 3$ contributes to the progression of human ovarian cancer. Oncogene 28:1320-1328. https://doi.org/ 10.1038/onc. 2008.475

Yang LP, Jiang FJ, Wu GS, Deng K, Wen M, Zhou X, Hong X, Zhu MX, Luo HR (2015) Acute treatment with a novel TRPC4/C5 channel inhibitor produces antidepressant and anxiolytic-like effects in mice. PLoS ONE 10:e0136255. https://doi.org/10. 1371/journal.pone.0136255

Yang Y, Pei K, Zhang Q, Wang D, Feng H, Du Z, Zhang C, Gao Z, Yang W, Wu J, Li Y (2020) Salvianolic acid B ameliorates atherosclerosis via inhibiting YAP/TAZ/JNK signaling pathway in endothelial cells and pericytes. Biochim Biophys Acta Mol Cell Biol Lipids 1865:158779. https://doi.org/10.1016/j.bbalip.2020. 158779

Yao H, Zhang Y, Shu H, Xie B, Tao Y, Yuan Y, Shang Y, Yuan S, Zhang J (2019) Hyperforin promotes post-stroke neuroangiogenesis via astrocytic IL-6-mediated negative immune regulation in the ischemic brain. Front Cell Neurosci 13:201. https://doi.org/ 10.3389/fncel.2019.00201

Yerna X, Schakman O, Ratbi I, Kreis A, Lepannetier S, de Clippele M, Achouri Y, Tajeddine N, Tissir F, Gualdani R, Gailly P (2020) Role of the TRPC1 channel in hippocampal long-term depression and in spatial memory extinction. Int J Mol Sci. https://doi.org/ 10.3390/ijms21051712

Yu Y, Fantozzi I, Remillard CV, Landsberg JW, Kunichika N, Platoshyn O, Tigno DD, Thistlethwaite PA, Rubin LJ, Yuan JX (2004) Enhanced expression of transient receptor potential channels in idiopathic pulmonary arterial hypertension. Proc Natl Acad Sci USA 101:13861-13866. https://doi.org/10.1073/pnas. 0405908101

Zhang X, Zhao Z, Ma L, Guo Y, Li X, Zhao L, Tian C, Tang X, Cheng D, Chen Z, Zhang L (2018a) The effects of transient receptor potential channel (TRPC) on airway smooth muscle cell isolated from asthma model mice. J Cell Biochem 119:6033-6044. https://doi.org/10.1002/jcb.26801

Zhang Y, Knight W, Chen S, Mohan A, Yan C (2018b) Multiprotein complex with TRPC (transient receptor potential-canonical) channel, PDE1C (phosphodiesterase 1C), and A2R (adenosine $\mathrm{A} 2$ receptor) plays a critical role in regulating cardiomyocyte cAMP and survival. Circulation 138:1988-2002. https://doi. org/10.1161/circulationaha.118.034189

Zhang Y, Yu P, Liu H, Yao H, Yao S, Yuan SY, Zhang JC (2019) Hyperforin improves post-stroke social isolation-induced exaggeration of PSD and PSA via TGF- $\beta$. Int J Mol Med 43:413425. https://doi.org/10.3892/ijmm.2018.3971

Zhang X, Deng Y, Xiang J (2020) Galangin improved non-alcoholic fatty liver disease in mice by promoting. Autophagy 14:33933405. https://doi.org/10.2147/dddt.s258187

Zhang S, Zhuang L, Liu Q, Yu X, Min Q, Chen M, Chen Q (2021) Rosiglitazone affects the progression of surgically-induced endometriosis in a rat model. Mol Med Rep. https://doi.org/ 10.3892/mmr.2020.11673

Zheng J (2013) Molecular mechanism of TRP channels. Compr Physiol 3:221-242. https://doi.org/10.1002/cphy.c120001

Zheng Z, Wang Y, Yu H, Li W, Wu J, Cai C, He Y (2020) Salvianolic acid $\mathrm{B}$ inhibits ototoxic drug-induced ototoxicity by suppression of the mitochondrial apoptosis pathway. J Cell Mol Med 24:6883-6897. https://doi.org/10.1111/jcmm.15345

Zhong X, Huang S, Liu D, Jiang Z, Jin Q, Li C, Da L, Yao Q, Wang D (2020) Galangin promotes cell apoptosis through suppression of H19 expression in hepatocellular carcinoma cells. Cancer Med 9:5546-5557. https://doi.org/10.1002/cam4.3195

Zhou Y, Castonguay P, Sidhom EH, Clark AR, Dvela-Levitt M, Kim S, Sieber J, Wieder N, Jung JY, Andreeva S, Reichardt J, Dubois F, Hoffmann SC, Basgen JM, Montesinos MS, Weins A, Johnson AC, Lander ES, Garrett MR, Hopkins CR, Greka A (2017) A small-molecule inhibitor of TRPC5 ion channels suppresses progressive kidney disease in animal models. Science 358:1332-1336. https://doi.org/10.1126/science.aal4178

Zhou B, Wang Y, Zhang C, Yang G, Zhang F, Yu B, Chai C, Cao Z (2018) Ribemansides A and B, TRPC6 inhibitors from ribes manshuricum that suppress TGF-beta1-induced fibrogenesis in HK-2 Cells. J Nat Prod 81:913-917. https://doi.org/10.1021/ acs.jnatprod.7b01037

Zhou Y, Li X, Chen K, Ba Q, Zhang X, Li J, Wang J, Wang H, Liu H (2020) Structural optimization and biological evaluation for novel artemisinin derivatives against liver and ovarian cancers. Eur J Med Chem. https://doi.org/10.1016/j.ejmech. 2020.113000

Zhu X, Chu PB, Peyton M, Birnbaumer L (1995) Molecular cloning of a widely expressed human homologue for the Drosophila trp gene. FEBS Lett 373:193-198. https://doi.org/10.1016/00145793(95)01038-g

Zhu X, Jiang M, Peyton M, Boulay G, Hurst R, Stefani E, Birnbaumer L (1996) trp, a novel mammalian gene family essential for agonist-activated capacitative $\mathrm{Ca}^{2+}$ entry. Cell 85:661-671. https:// doi.org/10.1016/s0092-8674(00)81233-7

Zhu Z, Luo Z, Ma S, Liu D (2011) TRP channels and their implications in metabolic diseases. Pflug Arch 461:211-223. https://doi.org/ 10.1007/s00424-010-0902-5

Zhu Y, Lu Y, Qu C, Miller M, Tian J, Thakur DP, Zhu J, Deng Z, Hu X, Wu M, McManus OB, Li M, Hong X, Zhu MX, Luo HR (2015) Identification and optimization of 2-aminobenzimidazole derivatives as novel inhibitors of TRPC4 and TRPC5 channels. Br J Pharmacol 172:3495-3509. https://doi.org/10.1111/bph.13140

Zhu Y, Gao M, Zhou T, Xie M, Mao A, Feng L, Yao X, Wong WT, Ma X (2019) The TRPC5 channel regulates angiogenesis and promotes recovery from ischemic injury in mice. $\mathrm{J}$ Biol Chem 294:28-37. https://doi.org/10.1074/jbc.RA118.005392 
Zou Y, Li R, Kuang D, Zuo M, Li W, Tong W, Jiang L, Zhou M, Chen Y, Gong W, Liu L (2020) Galangin inhibits cholangiocarcinoma cell growth and metastasis through downregulation of MicroRNA-21 expression. BioMed Res Int. https://doi.org/10.1155/ $2020 / 5846938$
Publisher's Note Springer Nature remains neutral with regard to jurisdictional claims in published maps and institutional affiliations. 